\title{
Biological Innovation without Intellectual Property Rights: Cottonseed Markets in the Antebellum American South
}

Paul W. Rhode

The Antebellum American South experienced rapid biological innovation centered around an active market for new cotton seed varieties, despite the absence of intellectual property rights. Contemporaries complained new seed was initially offered at high prices, which subsequently collapsed. Using local newspaper evidence, this paper documents this market's operation. It then rationalizes the price movements given the potential of improved seed to multiply at finite rates. The initial prices were sufficiently high to provide meaningful incentives to innovate. This study also identifies information problems affecting the cotton seed market, leading observers to claim too many new varieties were released, not too few.

$\mathrm{I}^{\mathrm{n}}$ n early 2013, the U.S. Supreme Court heard the case of Bowman v. Monsanto Co. (657 F.3d 1341) concerning whether a farmer could "reproduce patented seed through planting and harvesting without the patent holder's permission." During oral arguments, Chief Justice John Roberts signaled his skepticism of farmer Bowman's claim that Monsanto's patent rights for Roundup-Ready soybean seed were exhausted after the initial authorized sale. Roberts inquired: "Why in the world would anybody spend any money to try to improve the seed if as soon as they sold the first one anybody could grow more and have as many of those seeds as they want?" (19 February 2013, Proceeding, p. 3). On 13 May 2013, Justice Elena Kagan delivered the Court's unanimous opinion in Monsanto's favor. If protection were exhausted at sale, "Monsanto's patent would provide scant benefit. After Monsanto sold its first seed, other seed companies could produce seed to compete with Monsanto, and farmers would need to buy seed only once." This entailed "depriving Monsanto of its monopoly" (p. 6). By passing the Patent Act

The Journal of Economic History, Vol. 81, No. 1 (March 2021). (C) The Economic History Association. doi: 10.1017/S0022050720000662. This is an Open Access article, distributed under the terms of the Creative Commons Attribution license (http://creativecommons.org/ licenses/by/4.0/), which permits unrestricted re-use, distribution, and reproduction in any medium, provided the original work is properly cited.

Paul W. Rhode is Professor, University of Michigan - Economics, 611 Tappan St. Ann Arbor Michigan 48109-1220, USA. E-mail: pwrhode@umich.edu.

I would like to acknowledge the helpful comments of Richard Baker, Lisa Cook, Avner Greif, Naomi Lamoreaux, Petra Moser, Alan Olmstead, Mark Stegeman, and audience members at Boston University, Clemson, UC-Davis, Michigan, Stanford, Yale, and the Western International Economic Association meetings. I am also grateful for the editorial advice of William Collins and three referees for substantially improving this piece. 
to provide incentives for innovation, Congress had intended to create an "undiluted patent monopoly" for 20 years, not "for only one transaction" (p. 8) (see also Liptak (2013)). The U.S. Supreme Court decision reflects the common argument that intellectual property rights (IPRs) are necessary to promote rapid innovation. To encourage the invention of self-replicating products such as seed or software, strong protection is viewed as essential.

Justice Roberts' line of inquiry is ahistorical and universalist. It ignores specific examples of precisely the innovative behavior that he questioned. This paper examines one notable historical example. Without any form of IPRs for plants, the upland cotton sector of American South in the antebellum period witnessed significant biological innovation. Seed improvers introduced a succession of new cotton varieties - first green seed, then Mexican white seed and Petit Gulf, and many other new varieties thereafter - that greatly increased the productivity of the region's land and labor. These developments are surprising because they occurred in the American South, a region with a large enslaved and disempowered labor force, limited pools of skilled workers, few sizeable cities, a weak commitment to patent enforcement, and a general reputation for technological backwardness.

As an indication of the region's productivity advance, Olmstead and Rhode (2008b, pp. 1123-71) show that the amount of cotton picked per worker per day increased four-fold between 1800 and 1860 . Contemporaries asserted the improved seeds rivaled the importance of the invention of Eli Whitney's saw gin. These biological innovations helped the American South become the dominant global producer of cotton, supplying three-quarters of the key raw material to the industrializing world circa 1860. The British East India Company, the Ottoman Sultan, and planters in the Antipodes all recognized that the U.S. comparative advantage in cotton production was, in large part, based on its superior seeds. These competing producers actively imported improved cotton seeds from America and hired southern planters who knew how to grow them.

Seeds, by their nature, carry instructions to multiply themselves in large numbers. Assuming no cross pollination, the copies are nearly exact. This meant that farmers could purchase improved seed and imitate the innovation by planting and increasing it on their property. The advent of technologies and laws that limited reproducing commercial seed such as the F1/F2 hybridization process (1910s/20s) and intellectual property protection for sexually-reproduced plants (1970s in the United States) as well as the terminator gene (1998) restructured the market for improved seed. These changes made it easier for commercial breeders to appropriate 
the returns from their innovations to cover the cost of their investments while at the same time limited the ability of farmers or rival breeders to reproduce seed. However, at an earlier age prior to these developments, seeds were commercial products. In the antebellum American South, the market for cotton seed for planting purposes thrived, promoting significant rates of innovation and productivity growth in the complete absence of IPRs.

To frame the analysis of this paper, it is important to establish some "stylized facts" about cotton seed and its power to multiply. Unlike grain crops, cotton was not grown for its seed. Lint, the seed's covering, was a "good." The seed, at least before the discovery of ways to utilize it for feed, fertilizer, and oil, was a "bad." (Untreated cotton seed is poisonous to many mammals and fish.) Depending on the variety grown, seed made up between two-thirds to three-quarters of the product of a cotton field by weight. It was bulky, weighing between 25 to 33 pounds per bushel. (Assuming 30 pounds will serve our purposes.) Circa 1849-50, given typical seeding rates of 2.5 bushels per acre, yields of 600 pounds of seed cotton per acre, and a turn-out ratio of 1 pound of lint and 2 pounds of seed, the seed would multiply 5.33 fold each year. The multiplication ratio could be far higher if greater care was taken. With these crude parameters, the powers of multiplication were sufficiently rapid that, within 17 years, the progeny of a single seed could plant all of the 5 million acres devoted to cotton in the South in $1849 .{ }^{1}$ This rate of increase was finite and far slower than Justice Roberts' hypothetical where as soon as the first seed was sold, "anybody could grow more and have as many of those seeds as they want." The conditions of the breeders' market power were determined by the seed's reproductive rate and cultivation practices rather than by legislative choices and court proceedings. At the time, under the 1836 Patent Act, the term of a U.S. patent, which granted "the full and exclusive right and liberty of making, constructing, using, and vending to others to be used," was 14 years, with the possibility of renewal for an additional 7 years.

The makeup of the cotton plant contributed to the early development of the seed market. The large concentrations of mixed populations of cotton plants with cross-pollination in the field and heterozygosity created a

\footnotetext{
${ }^{1}$ For standard seeding rates circa 1850 , see p. 658 of the 1848 Annual Report of the U.S. Patent Office (1849). In 1849 there were 2,443,793 bales of $400 \mathrm{lb}$ of ginned cotton produced on an estimated 5 million acres in the United States. This represents a yield of $195.51 \mathrm{~b}$ of lint per acre. See U.S. Census Office (1854, pp. 174, 176). The calculation assumes there are 120,000 seeds per bushel. See Brown (1927, p. 78). Taking a multiplication rate of 5.333 per year, the time is $\mathrm{T}=16.75$ years. This multiplication rate is likely on the low side because cotton growers could economize on the use of the seed.
} 
high potential for genetic change. This plasticity made it possible for astute breeders to find and develop productivity-enhancing varieties, but these conditions also caused "deterioration" or scrambling of existing combinations. This created a demand for fresh seed. Planting shocks, such as late-season freezes, also stimulated demand for replacement seed. In addition, seeds are compact, relatively durable, and easily transported, enhancing their efficiency as carriers of technology.

This paper first describes the operation of the antebellum U.S. cotton seed market and lays out the legal and institutional setting, placing particular emphasis on the absence of IPRs. It then documents the rapid introduction of new varieties after the mid-1830s and investigates the market's information problems and insiders' efforts to police them. The paper next develops a new model of the markets for cotton seed inspired by Boldrin and Levine (2008). The model captures the effects of the expansion of supply on the market with homogeneous purchasers with complete information. Finally, the paper builds and analyzes a dataset of price quotes and shows the price path for high-quality seed largely conforms to the predictions of the model. High Initial Public Offering (IPO) prices provided significant (if not fully optimal) incentives for seed suppliers to introduce new and improved cotton seed in the absence of IPRs.

\section{THE OPERATION OF THE COTTON BREEDING BUSINESS}

In 1854, a writer in Harper's Magazine summarized the dynamics of the cotton seed market in the late-antebellum period: "whenever, by good fortune, a higher-yielding cotton plant appears 'instantly . . . the local newspapers teem with advertisements and commission houses are filled with the magic seed"' (Thorpe 1854, p. 449). In 1868, Joseph Lyman observed: "Beginning with the year 1820, and from that time forward, various planters in different parts of the cotton growing States have devoted themselves to the development and sale of improved varieties of cotton seed, and certain styles of cotton have for two, three, or four years, enjoyed a great, though ephemeral popularity, and, then, as suddenly, been pushed aside for a new reigning favorite. The improvement of a cotton seed as a business, and sale of the improved varieties, has enabled quite a number of prominent and enterprising planters throughout the South to realize handsome fortunes" (Lyman 1868, p. 121). Among those prominent in antebellum seed business were Rush and Hall Nutt of Jefferson County, Mississippi; Richard Abbey of Yazoo City, Mississippi; Henry W. Vick of Vicksburg, Mississippi, and his associate, Martin W. Philips; 
G. D. Mitchell of Warren County, Mississippi; and David Dickson and Charles Peabody of Georgia. But many others participated. ${ }^{2}$

A rich source of information about the antebellum cotton seed market is the southern press, and especially the numerous advertisements and introductory announcements appearing from the $1830 \mathrm{~s}$ on. In most of the classified ads, an established local merchant placed a few lines noting the availability of supplies of improved seed. Sometimes, they offered potential purchasers the opportunity to inspect sample bolls or bearing stalks of the new variety. With a prized new variety, a breeder or his local agents went all out, placing large ads announcing its debut. Such ads cataloged the new variety's characteristics, including its fiber quality and picking rates, provided a story of its origins, and offered testimonials (also known as "certificates") by prominent planters (Philips 1855a). While the ads rarely offered potential customers a free chance to try the seed, they often claimed to warrantee its authenticity.

The commercial cotton seed breeding sector thrived in the antebellum period despite an absence of patents, copyrights, substantial monetary prizes, or large investments by the federal or state governments. The U.S. federal government did provide early vital assistance to the upland cotton sector. While visiting Mexico City as a part of an American mission in 1806, Walter Burling obtained seeds of a high-quality cotton, which he smuggled out of Spanish Mexico and then passed on to his Natchez area neighbor, William Dunbar, for experimentation and acclimatization. Over the next two decades, breeders in the Mississippi Valley crossed Mexican highland cotton with local stock to create varieties that possessed higherquality lint, greater resistance to disease (especially to the "rot"), higher yields per acre, and greater ease of picking. Burling's piracy was not part of official policy.

In 1819, the U.S. Treasury instructed its overseas officials and Navy officers to identify and send to the United States any foreign plants likely to be of value. The justification for such publicly-funded investments was that private farmers and breeders would be unable to capture the benefits of the new seeds they introduced. But such public actions were more substitutes for than complement to private efforts.

The U.S. Patent Office, under Commissioner Henry Ellsworth, became the center of the federal seed importation and distribution system in the mid-1830s. At first, Congressional representatives used their franking privileges to send seed to constituents. In 1839, Congress appropriated

\footnotetext{
${ }^{2}$ As early as 1857 , one scientist, John Griffin, began the laborious process of hybridizing new cotton varieties. See Olmstead and Rhode (2008a, 2008b).
} 
money to the Patent Office to perform the task. In 1857, the Patent Office established a germination garden to multiply its supplies. In the late 1850 s, the Office spent $\$ 45-85$ thousand per year for the "Collection of agricultural statistics and procuring and distributing seeds and cuttings," with the bulk of the money for the latter purposes (U.S. Treasury, various years, 1854-1862). The number of packages of seeds distributed grew from 30 thousand in 1840 to 80 thousand in 1849 to 474 thousand in 1861; the cumulative number distributed by 1861 reached almost 2.5 million packages (see True (1937, pp. 25-34); Dupree (1957, pp. 110-12); Kloppenberg (2004, pp. 61-62); Fullilove (2017, pp. 44-66)).

But the U.S. Patent Office issued no IPRs for plants. The Patent Acts of 1790 and 1836 provided no coverage. Indeed, there were no patent rights for plants until the passage of the Plant Patent Act of 1930, which covered only asexually-reproduced plants. (And even then, there was a carve-out excluding tubers.) Given the state of scientific knowledge in the antebellum period, it is unclear how property rights in plant varieties could have been enforced.

The Patent Office's Annual Reports in the late 1840s and early 1850s did include extensive commentary regarding cotton varieties, giving an official outlet for the opinions of Martin W. Philips. The governments of the southern states also played limited roles. Apart from the Savannah Gardens in colonial Georgia, none funded experiment stations conducting research on cotton during this period. In the late-antebellum period, some private individuals, such as Philips (1848a, 1848b, 1849, $1855 \mathrm{~b}$ ) and Jones (1852), conducted ambitious agricultural experiments and disseminated their findings.

As a part of the general agricultural reform movement, the southern states did charter agricultural societies and sponsor state and local fairs. By the 1850 s, such fairs often held contests with honors, including monetary prizes, for the best cotton. But it would be wrong to treat the antebellum cotton seed industry as an example where prizes successfully replaced patents as the inducement to innovate. The prize stakes were small. The example of Jethro cotton illustrates how awards added value in the market (see Albany Patriot (17 January 1851, p. 2), Philips (1851c, 1855b), and Jones (1852)). Jethro's favorable notice at the Crystal Palace exposition in London in 1851 and received the top prize for cotton lint at the New York version of the fair held in 1853. Publicity for the seed promptly featured this triumph. The New York Times (26 July 1853, p. 1) observed that "although the Crystal Palace contains many articles which make more show, and will attract more attention, it has none which have exercised a greater influence upon the civilization of world," than these cottons. 
Most upland cotton producers grew their crops without such publicity, devoting their private efforts to selecting and maintaining seed quality. If these efforts led to any improvement, the knowledge and seed spread no further than to close associates. But this was not due to concern for secrecy. Vick and Philips publicized their innovations broadly and were quite open to sharing their new seeds with fellow breeders. In a letter in the 1850 Annual Report of the U.S. Commissioner of Patents (Part II, p, 262), Philips wrote "My crop is always open to inspection; I procure the best seed of each variety, and am willing to send "for persons and papers,' and submit the case to a jury of all the cotton-planters." During the 1835-61 period, the agricultural improvers did not complain about the secrecy of the upland cotton producers but rather about excessive hype and high-priced "humbugs." Agricultural journalists and reformers focused on unwarranted publicity for untried new varieties and on proliferation of new names for old varieties. Introductions were like the Mississippi bubble - a very high price justified only by selling to others who sell to others - all before something better came along.

It is germane to compare the rapid progress in upland cotton breeding with the more closed world of Sea Island cotton breeding and production (Porcher and Fick 2005; Gray 1933, vol. 2, pp. 675-78). In this narrow niche-oriented sector, prominent planters limited access to their improved seed and closely guarded secrets about their special preparation and processing techniques. Sea Island planters followed their practices as rice producers (Coclanis 1989). Differences between upland and Sea Island sectors also show up in the records of productivity advance. In contrast to the quadrupling of picking rates in the open-technology upland cotton sector, harvest productivity in the more closed Sea Island sector remained essentially constant over the antebellum period.

Even within the upland cotton sector, there were important differences between southern seed breeders. These may be divided, roughly speaking, into three camps along the dimensions of permanence and innovativeness. The first camp was a stable set of producers of standardized high-quality varieties such as Petit Gulf. They sold under brand names through established merchant networks without much fanfare. The second camp was comprised of the one-time discoverers or importers of new varieties. These one-shot wonders were often marketed as revolutionary new introductions. Moore (1956, pp. 98-99) notes some imported seed from Asia, Africa, or Latin America, whereas others found "accidental mutations among their ordinary Mexican cotton." The third camp combined attributes of the other two, working systematically to breed a series of new better cottons. Such producers sought long-run reputations 
for their innovative efforts. Within this third camp, many of the breeders formed social networks to share knowledge and genetic material. ${ }^{3}$ They gave each other credit for advances as well as heaped scorn on others for copying the seeds without proper acknowledgment. Some in this group tied their seed business with other commercial endeavors such as selling fertilizer or publishing farm journals.

Leading upland cotton breeders were typically high-status planters with additional professions such as a physician, minister, journalist, or merchant. Though it was rare for breeders to be politicians or lawyers, a surprisingly high proportion appear to be associated with the Whig party. Abbey, Vick, and Dickson were all Whigs; Philips was involved in Democratic party politics in the 1850s (Riley 1909, p. 456). All were white males. Few were yeoman farmers. None of them were the enslaved African-Americans who planted, cultivated, and harvested the vast majority of the U.S. cotton crop. (See Cook (2011) for an analysis of African-American innovative activity in other sectors.) Accounts such as Sokoloff and Khan (1990), Khan and Sokoloff (1993), and Khan (2005) heralding the democratic nature of American invention have little purchase in cotton breeding. But, of course, those accounts focus on patenting activity, which did not cover plant breeding. The view from the top was also different; the most elite southerners were rarely seed breeders. Among the names appearing in the cotton seed advertisements, only Martin W. Philips was listed in the Dictionary of American Biography.

\section{THE ANTEBELLUM MARKET FOR NEW UPLAND COTTON VARIETIES}

The active market for improved upland cotton seed dated to the early 1830 s; the seed advertisements became a common-place in southern newspapers from this period forward. As evidence for this timing, Figure 1 graphs indices of newspaper hits for "Cotton Seed" in five major digital databases of historical newspapers-Chronicling America, Readex Early American Newspapers, Access NewspaperArchive, Ancestry's Newspaper.com, and Genealogy Bank - by five-year period from 1810 to 1859. For each database, the index is formed as the ratio (times 100) of hits for "Cotton seed" minus hits for "Cotton seed oil," all divided hits for "Cotton." Mentions of "Cotton seed oil," a product which becomes

\footnotetext{
${ }^{3}$ For recent work on innovation networks, see Thomson (2009, pp. 100-28) and Meyer (2006, pp. 8-15).
} 


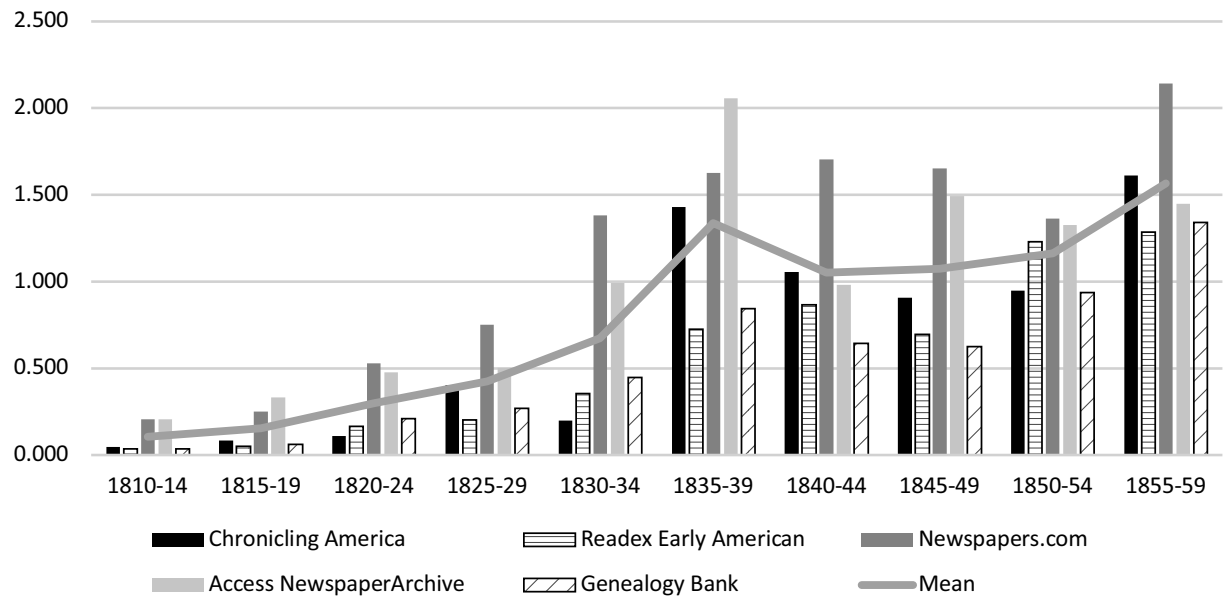

FIGURE 1

INDICES OF "COTTON SEED HITS"

Note: The index was formed as $100 *$ (Hits(Cotton seed)-Hits(Cotton seed oil))/Hits(Cotton). Sources: Compiled based on a search of the following digital databases of historical newspapers: Chronicling America; Readex Early American newspapers, Access NewspaperArchive, Ancestry's Newspaper.com, and Genealogy Bank. Each database was searched using the terms "Cotton," "Cotton Seed," and "Cotton seed oil."

important in the $1850 \mathrm{~s}$, are excluded to focus attention on the planting uses of seed. Coverage is restricted to U.S. newspapers. The indices vary across the databases, but the overall pattern is clear. The relative mentions of "Cotton Seed" are far greater after 1835 than before 1830.

Among the first star products was Petit Gulf, a Mexican highland selection produced in the Petit Gulf/Rodney/Gulf Hills region of Mississippi. Commercial seed producers from many parts of the Mississippi Valley affixed the "Petit Gulf" name to their bags of seed (Gray 1933, p. 703). ${ }^{4}$ Standard accounts credit the development of Petit Gulf to Dr. Rush Nutt. He learned the secrets of Llewellyn Price, a pioneering breeder in the 1820 s, and made them a commercial success. Rush Nutt and his family produced improved seed under their own brand, acquiring a regional and even international reputation (Nutt 1841, pp. 312-14; Moore 1956, p. 98).

Other "improved" varieties - including one alternatively called Okra, Twin, or Alvarado - joined Petit Gulf on the market in the late 1830s. The story of Okra cotton is illustrative of one source of innovation and

\footnotetext{
${ }^{4}$ In his 2013 book, River of Dark Dreams, Johnson mangles the history of cotton improvement, focusing virtually all attention on Petit Gulf to the exclusion of earlier and later varieties. He (p. 8) incorrectly labels Petit Gulf as Gossypium barbadense rather than as Gossypium hirsutum, that is, as Sea Island rather than as upland cotton. And he (p. 152) incorrectly claims that Petit Gulf was "patented," which was impossible under prevailing U.S. intellectual property law. He appears to misread Smith and Cothren (1999).
} 
the evolving set of marketing practices. Todd Terry of Autauga, Alabama discovered a distinct plant in a field of Petit Gulf cotton-it bore its cotton on the main stem and had no branches. It looked like an okra plant, a close relative to cotton, hence its name. The unusual stalk was picked clean except for a single lock containing nine seeds. From these seeds, Terry propagated the strange plant, which was very tall and matured early. It was thought to be easier to pick, grow in a way allowing closer planting, and have a longer tap root enhancing its drought resistance. In 1837, Terry marketed seeds for 50 cents each, nearly $\$ 14$ per seed in today's purchasing power, and \$160 per bushel in 1838 (Farmer's Register, 30 April 1839, p. 252; Niles' National Register, 7 September 1838, p. 24; American Farmer, 11 September 1839, p. 127; Southern Banner, 27 September 1839 , p. 3). The variety gained strong adherents such as Dr. D. Cooper of Harris Co. Georgia; Cooper "is thoroughly convinced of the superiority of this Cotton, and is taking great pains to disseminate it through the Cotton growing region" (Southern Banner, 27 September 1839, p. 3 ). Advertisements touted the advantages of growing the seed not just for oneself but also as a speculative venture to supply others: "The small amount of the seed now in existence will make their production an object of great importance for some time to come; and persons not disposed to go into the culture of cotton, would probably realize great profit by planting with a view to sell the seed" (Southern Banner, 4 October 1839, p. 3).

The practice of advertising Okra seed as an investment vehicle represented a departure. In an editorial that was widely reprinted, Edmund Ruffin of the Farmer's Register (30 April 1839, p. 252) criticized the marketing of Okra:

If, according to the heretofore liberal and universal procedure of southern agriculturists, the first holders of this variety of cotton, had offered to give away seeds, or to sell them at merely a fully remunerating price, few persons would have cared to plant them. But by pursuing the contrary course, and asking fifty cents a seed, the anxiety to obtain them has probably been increased in the ratio of the advance of price. All this is well, if confided to real improvements; and if such cannot be introduced by operating by means of reason and sound precept, it is certainly desirable that it should be done by operating on the credulity and folly of the recipients. But, unfortunately, it has come to be considered that the high price asked for new seeds, \&c., is alone sufficient evidence of their intrinsic value; and hence dupes are continually made by the vilest and grossest impositions that can be imagined.

When the distinctive biological features of Okra proved to have no great productivity or marketing advantages, critics charged these new seeds were "humbugs," frauds perpetrated on a gullible public. 
Ruffin and his fellow farm journalists compared humbuggery in the cotton seed market to other speculative fads affecting farmers in the early nineteenth century. These included so-called Morus Multicaulis mania also raging in the late 1830s (Farmers' Cabinet, 15 October 1838, p. 80, 15 December 1838, pp. 154-56). Morus Multicaulis was the fast-growing Chinese mulberry tree favored by silk-raisers. Gideon Smith of Baltimore, $\mathrm{MD}$, first introduced its cultivation to America in 1826. Excitement about the tree "grew steadily, slowly... at first, but increasing with a geometrical progression...The young trees or cuttings, which were sold in 1834 or 1835 for $\$ 3$ or $\$ 5$ a hundred, came soon to be worth $\$ 25, \$ 50, \$ 100, \$ 200$, and even $\$ 500$ a hundred.... The times were rife with speculation." The plants were sold with the prospect of being multiplied and marketed to others the next season. The bubble burst in 1839/40, leaving the mulberry cultivators "in utter ruin." (Quotes from Brockett (1876, p. 39); see also Cole 1926, pp. 622-39.) This episode colored the views of many farmers, planters, and journalists in the 1840s and 1850s about the value of biological innovations such as new varieties of cotton seed.

A marked contrast was the story of One Hundred Seed, a cotton variety bred and distributed by Col. Henry W. Vick of Vicksburg, Mississippi (Moore 1956, pp. 95-104, 1988, pp. 12-16). In the classic book Cotton Culture, Lyman (1868, p. 122) called Vick: "the most persevering and the most successful of all the Mississippi planters in the art of perfecting cotton." Vick owned a large plantation in Issaquena County. After noting the differences between individual plants in a field of Petit Gulf cotton, he became interested in cotton breeding. In 1839, Vick began an annual process of having his most able slaves make special pickings in which they harvested only the finest bolls from the largest and most prolific plants. This cotton was ginned separately and then grown in isolated fields. Vick often ventured into the fields himself in search of valuable mutations and crosses. He personally selected the progenitor of the One Hundred Seed variety in 1843 from the particularly appealing bolls of a single plant, which he discovered while visiting another plantation in the Delta (Vicksburg Sentinel, 7 July 1847, p. 1). He then increased this seed for a few years before marketing it. In the words of Martin W. Philips in the 1848 Annual Report of the U.S. Commissioner of Patents (1849, p. $155)$ "Vicks 100-seed is the result of the most patient, persevering, and scientific selections from the field, and a judicious selection in the house as to staple. It is Mexican or Petit Gulph highest improved."

Vick worked in close association with Philips, a physician and planter from Edward's Depot, Mississippi. Philips entered into the cotton seed business after his medical practice languished in the late $1830 \mathrm{~s}$. He 
engaged principally in testing, multiplying, and marketing the new varieties that Vick bred and selected. Even without IPRs, a pattern of specialization emerged: Philips commercialized the innovations that Vick generated. Philips was also an energetic publicist and promoter. He founded and edited the short-lived South-Western Farmer in the mid-1840s and was an indefatigable correspondent on agricultural topics - most notably on improved cotton seed-for the Southern Cultivator, American Agriculturist, American Cotton Planter, South Carolina Temperance Advocate, among other outlets. His activities were tied with other leading southern agricultural reformers, including Edmund Ruffin, J. J. Jones, Noah B. Cloud, and Thomas Affleck. The collaboration of Philips and Vick represented the successful exploitation of division of innovative labor between the performance of $R \& D$ and the commercialization of the resulting products - one of the purported advantages of formal IPRs such as a patent system with assignment (Gans, Hsu, and Stern 2008).

The most celebrated new seed of the mid-1840s was Mastodon, a variety named for its large and wooly bolls. Richard Abbey, a Methodist minister from Yazoo City, Mississippi, introduced the new seed for the 1845 crop year. He had purportedly imported the seed from Mexico City in 1841 (American Agriculturist, January 1845, p. 37; Southern Cultivator, September 1846, p. 141). He claimed it increased production by 50-100 percent (Mississippi Free Trader, 16 November 1844, p. 1). The southern press widely covered the premium cotton, which won prizes at fairs across the South (Mississippi Free Trader, 8 November 1845, p. 1; Raymond Gazette, 26 December 1845, p. 1; DeBow's Review, February 1846, pp. 166-68). As part his endeavor to gain influence, Abbey sent a sample in early 1846 to former Vice President John C. Calhoun, adding Mastodon "has acquired a reputation beyond any thing (sic) I had anticipated.... I regard it a great Southern improvement" (Calhoun and Wilson 1995 , p. 440). In October 1845, Abbey started advertising the seed for $\$ 1$ per bushel (Yazoo Democrat, 8 October 1845, p. 3; Yazoo City Whig, 7 November 1845 , p. 2). With supplies running out, he raised the price in November to $\$ 2$ and by late December to $\$ 4$ per bushel (Yazoo City Whig, 14 November 1845, p. 2, 26 December 1845, p. 4; Yazoo Democrat, 26 November 1845, p. 2). Abbey, it was reported, earned $\$ 20$ thousand - the equivalent of more than $\$ 600$ thousand in current purchasing powerduring the Mastodon boom (Southern Cultivator, January 1850, p. 5). At an average price of $\$ 4$ per bushel, the new seed sold for a substantial premium relative to Petit Gulf-which regularly went for $\$ 0.50$ to $\$ 1.00$ per bushel - but never reached the level of Okra/Twin at its height. 
In addition to its distinctive appearance, Mastodon had several special features. The fiber clung to the plant, allowing its harvest to be delayed until the other crops were brought in. But planters did not find this flexibility of much value. Mastodon had a very long staple length. Its promoters believed it could be produced on upland cotton areas but compete with Sea Island cotton in the market. Its lint purportedly at first sold locally for 16 cents a pound when standard upland cotton sold for 8-10 cents a pound (Mississippi Free Trader, 1 January 1846, p. 1). But after Liverpool merchants rejected the variety following a widelypublished trial, Mastodon lost favor (American Agriculturist, March 1847, p. 90). The use of conventional saw gins also proved harmful. By mid-1847, the American Agriculturist (July 1847, p. 227) recorded that several communicants pronounced Mastodon a "gross humbug on the planting interest," but the publication chose to "not condemn too hastily" and instead awaited further trials.

A succession of celebrated varieties produced by Mississippi Valley breeders came on the market in the mid- and late 1840s. These included Sugar Loaf (1843), Boyd's Prolific (circa 1847), Hogan (1847), Banana (before 1848), Pomegranate (1849), and Jethro (1848). Sugar Loaf was first in the line of cluster types (i.e., the plant tended to have multiple bolls at each node on its short fruiting limbs, making the bolls cluster together). Boyd's Prolific was the pioneer variety in the semi-cluster line (which possessed the clustering habit in a less pronounced form). While dating to or before 1847, Boyd's Prolific was not extensively marketing until the mid-1850s (see New Orleans Commercial Bulletin, 14 February 1855, p. 2; Edgefield [SC] Advertiser, 12 March 1856, p. 2). Some represented improvements for specific locales; others were disappointments (Ware 1950, pp. 12-14; Phillips 1918, pp. 222-23).

By the mid-1850s, David Dickson and Charles Peabody became important seed breeders in South Atlantic states. Dickson began by selling Boyd's Extra Prolific and moved to market his own Dickson's Select Seed. Advertisements, displayed in Figure 2, document his expanding market presence. The 1854 ad lists 12 agents, all but one in Georgia, whereas the 1860 ad shows a network of 20 plus agents extended across the South, from North Carolina to Texas (Southern Cultivator, December 1860, p. 401). As he later put it: "I went into the business of selling cotton seed unwillingly, but it has paid me very well..." (emphasis added, letter quoted in Smith (1870, p. 157); see also Bonner (1943, p. 482)).

Plantation records show that planters paid prices in line with the newspaper quotes. For example, in April 1839, Nicholas Massenburg of Franklin County, NC, reported buying two seeds of Twin cotton, 


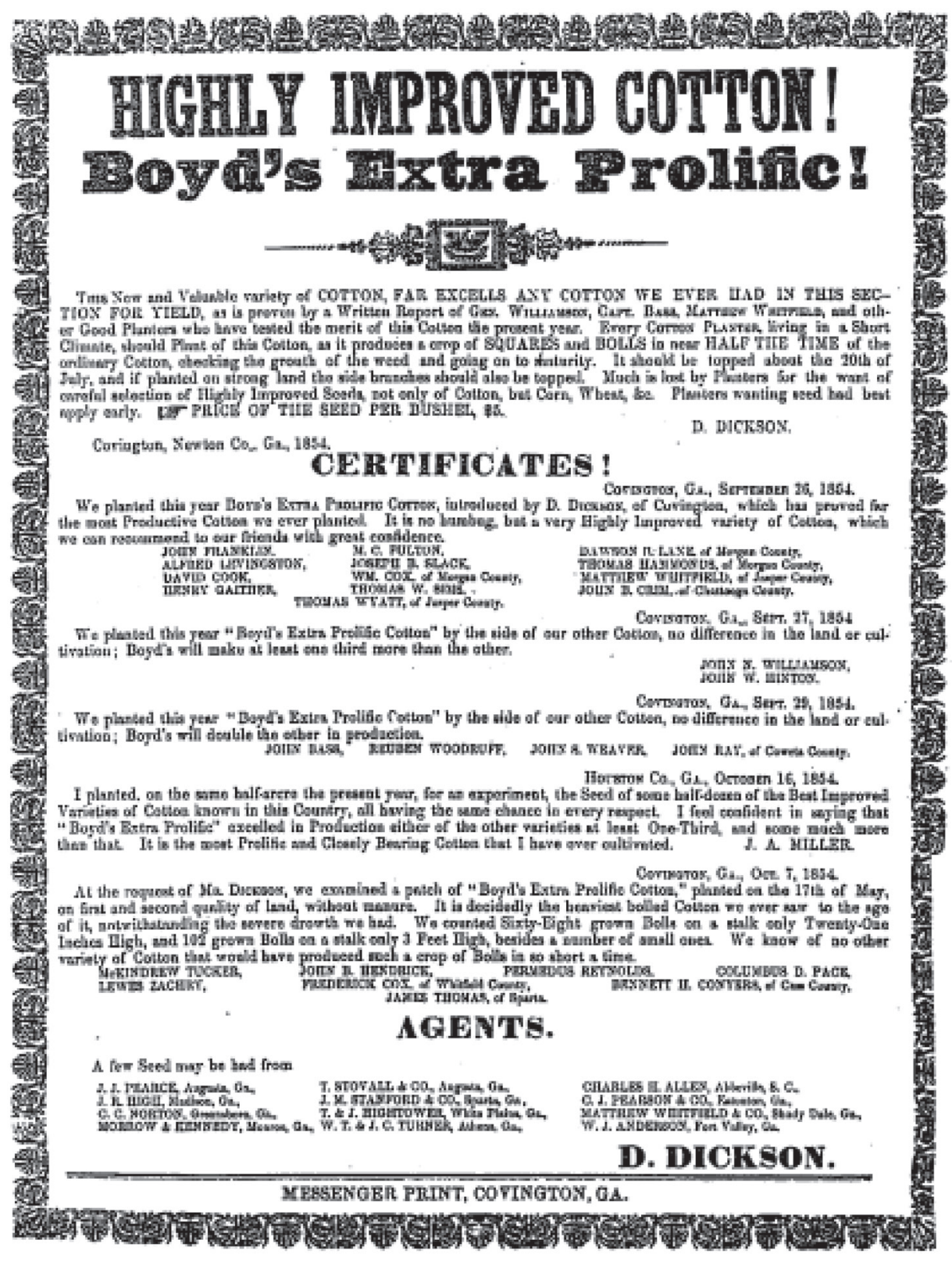

FIGURE 2

DAVID DICKSON'S SEED ADVERTISEMENTS FROM 1854 AND 1860

Sources: Highly Improved Cotton: Hargrett Library Broadside Collection, 1850-1859, Mss. 2622, Hargrett Rare Book \& Manuscript Library, University of Georgia Libraries. Improved Cotton: Southern Cultivator, Dec. 1860. 


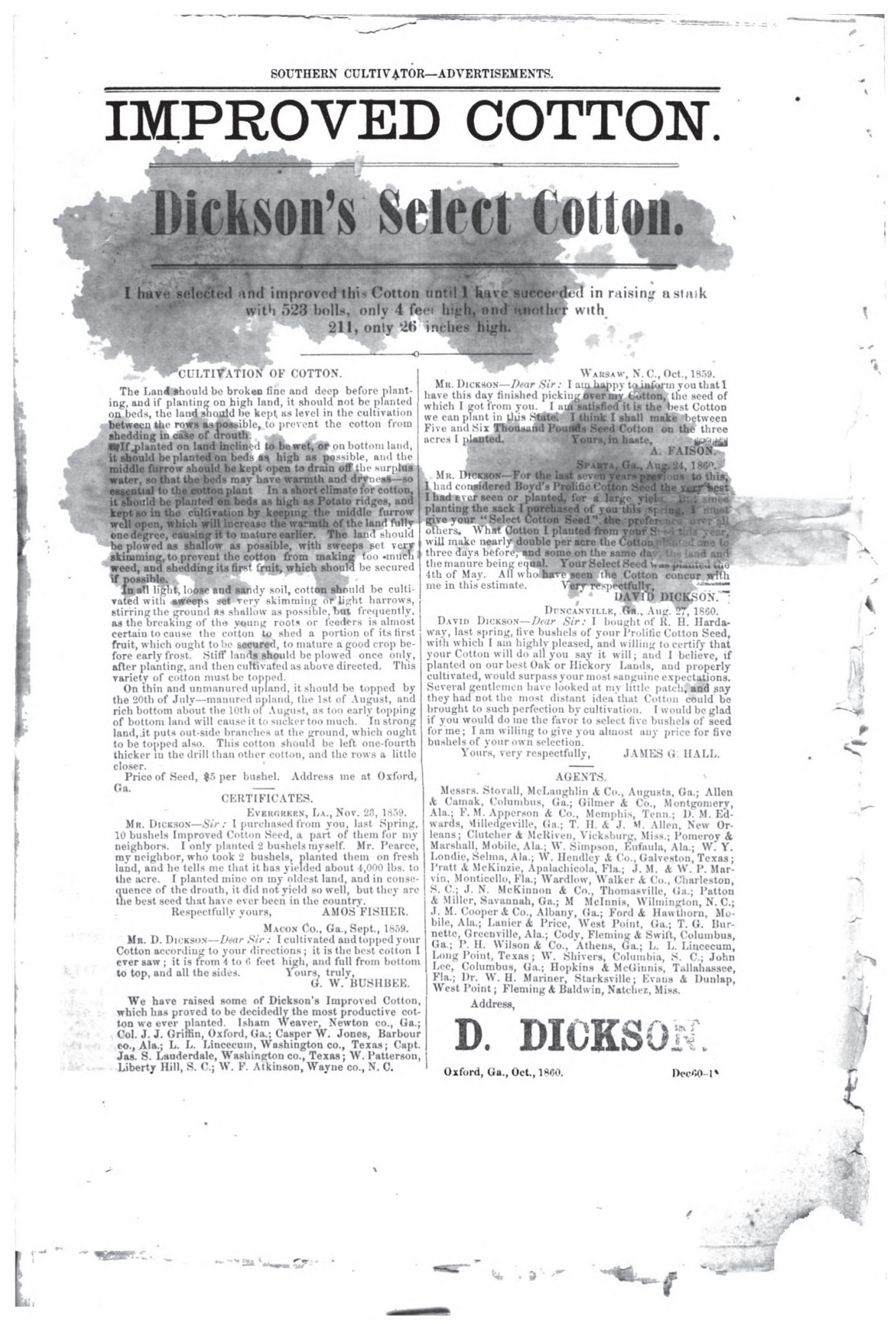

FIGURE 2 (CONTINUED)

DAVID DICKSON'S SEED ADVERTISEMENTS FROM 1854 AND 1860

Sources: Highly Improved Cotton: Hargrett Library Broadside Collection, 1850-1859, Mss. 2622, Hargrett Rare Book \& Manuscript Library, University of Georgia Libraries. Improved Cotton: Southern Cultivator, Dec. 1860. 
"for which I paid 50 cent each." Walter Wade of Jefferson County, MS, purchased Mastodon cotton for a price near newspaper quotations. Robert Jenkins of Adams County, MS, paid one dollar per bushel for a large load of Prolific seed in 1847, again near the prevailing newspaper rates. ${ }^{5}$

The names of advertised seeds appear repeatedly in plantation books. Hugh Davis of Perry Country, AL, planted a large number of varieties in 1850, including Prout, Tarver, Petit Gulf, and Sugar Loaf. By 1854, he winnowed down his list, principally growing Golden Chaff, Petit Gulf, and Willow (Jordan 1948, pp. 45-46). Francis Leak of Tippah, MS, reported growing Prolific, Lyles, Sugar Loaf, and Prout in 1848; in 1849, he grew Petit Gulf, Prout, Prolific, Magnolia, and Pomegranate. As another example, Julien Sidney Devereux of Rush County, TX, planted Prout, Golden Chaff, and Wilson seed in 1850; the next year he included Sugar Loaf. James Allen of Warren county, MS, planted at least four varieties of upland cotton-Georgia, India, Vicks, and Prolific-in $1860 .{ }^{6}$ Planting numerous varieties on the same plantation provided a form of insurance but also contributed to cross-pollination in the field and possible seed mixing in the gin.

The plantation records also attest to the popularity of new varieties, even controversial entries such as Twin, Mastodon, and Pomegranate. As noted earlier, Massenburg experimented with Twin seed in 1839. William Sim Reynolds of Barnwell, SC, planted the variety in a field the next year. ${ }^{7}$ In 1846, Leak, Wade, and James Henry Hammond of Silver Bluff, SC, all experimented with Mastodon. In 1847, Jenkins, Lewis Sterling of Feliciana Parish, LA, and McDonald Furman of Sumter County, SC, reported growing the new variety. ${ }^{8}$ Mastodon cotton acquired the reputation as a humbug, but Jones (1927, p. 205), among others, continued the seed long after it lost favor. A similar story holds for Mitchell's Pomegranate. Leak, John English of Aberdeen, MS, William Law of Darlington, SC, and Duncan McCall of Claiborne County, MS, all grew Pomegranate soon after it was introduced. As we see, leading improvers quickly charged the seed (or rather its branding) was a fraudulent, yet

\footnotetext{
${ }^{5}$ Massenberg papers, 24 April 1839; Wade, Ser. N, reel 18, 26 April 1846; Jenkins papers, 16 October 1846.

${ }^{6}$ Leak papers, Ser. J, Pt. 6, reel 25, frames 764, 794-814; Devereux papers, Ser. G, Pt 1. 28-29 March 1850; 27 March 1851; Allen papers, 11-17 April 1856.

${ }^{7}$ Reynolds papers 14 April 1840.

${ }^{8}$ Massenberg papers, 24 April 1839; Reynolds papers, 14 April 1840; Leak papers, Ser. J, Pt. 6, reel 25, frame 692-94; Wade papers, Ser. N Reel 18; 14 April 1846; Hammond papers, Ser. A, Pt. 1, reel 1, frame 357; Jenkins papers, 24 March 1847; Sterling papers, Ser. I, Pt. 2, reel 25, frame 103; Furman papers, FF 1287, p. 47.
} 
English, Law, and McCall continued to plant the seed through the early 1850s. . Vick's seeds, Boyd's Prolific and Sugar Loaf, which had untarnished reputations, were all very frequently mentioned in planters' records during the $1850 \mathrm{~s}$.

\section{CONFLICTS OVER SEED}

The cotton seed market had several problematic features. The cotton seed was closer to what economists call an experience good than an inspection good (Cabral 2005). Merchants might allow the planters to inspect samples of the lint, seeds, or plant, but it was difficult to ensure the seed was from the same stock as the sample. Some features were subject to inspection - in the 1820s, Mexican highland cotton had white seeds, distinct from green seeds of the prevailing varieties. But seed color lost its salience - soon there were bad white-seeded cotton and good, brownseeded Mexican cotton. Sellers would offer evidence such as shipping invoices or packaging material that the seed came from specific locations, such as Rodney, Mississippi, or specific breeders. Stores selling new seed would often display sample plants or stalks with open cotton bolls.

The buyers were not likely to be repeat customers for specific new introductions, and there was free entry for sellers into the market. If a new seed breeder sold a defective product (here meaning no real improvement), there was no threat of punishment. Nothing prevented that breeder from returning to the market later under a different name. Buyers, knowing this, had little reason to trust new seed breeders or to buy their product. Seed sellers responded by placing other forms of reputational capital on the line. Sellers of improved seed would be in the business of selling fertilizer and other supplies (D. Dickson), publishing agricultural improvement newspapers (J. Jones), or providing farming advice (M. Philips). In line with Klein and Leffler (1981), seed breeders engaged in extensive advertisement campaigns, making investments held hostage to the revelation of quality. The advertisements carried testimonials of local prominent planters, leveraging their reputations.

The newspapers and agricultural journals entered into complicated relationships with seed breeders, relationships fraught with conflicts of interest. Seed ads became a valued source of revenue for newspapers from the late 1830 s on. Promotions for new introductions could fill several column inches in the classified section of newspapers or even

\footnotetext{
${ }^{9}$ Leak, Ser. J, Pt. 6, reel 25, frames 794-814; English papers, 7 April 1853; Law papers, 1852 book, p. 2, 1853 book, p. 2; McCall papers, Ser. F5, Pt. 1, reel 5, frame 52.
} 
a full-page in a farm journal. In their own editorial pages, publishers often pointed out the paid advertisements for new seed and reviewed their claims favorably. They accepted letters (along with subscription renewals) from breeders touting their wares or published freely provided content from correspondents with an interest at stake.

A buyer could not be guaranteed the promised results would be reproduced on their own operation without planting. Experiments by buyers could be done on a small scale. If a supplier made a one-time discovery or introduced a foreign variety, the structure of the antebellum seed market created incentives to make a splash and sell at a high initial price soon after discovery. Playing on the seeds' capacity to multiply at high rates, the marketers sold the new seeds in small lots, from a pint (1/64 of a bushel) to even a single seed. But without a lengthy period of experimentation and testing, the new variety was likely genetically unstable. And attempts to multiply the supply internally, near existing production, created new problems. In the absence of care and isolation, cross-pollination with neighboring cotton plants threatened to compromise the variety.

We know that even a dedicated and attentive planter such as Martin W. Philips sowed different varieties of seed stock in close proximity (Riley 1909 , pp. 407, 415, 420-21, 436). It is likely that more typical planters did the same. In accounting for the failure of Mastodon, Richard Abbey blamed the planters and not the plant. In his letter introducing the seed, Abbey stressed to planters the necessity to keep the variety pure. He later complained that growers took insufficient care to prevent it from becoming "mixed and crossed" (Southern Cultivator, September 1846, p. 141). His brother, M. Ellis Abbey, asserted this showed "the folly of purchasing 'a few bushels to get a start'..." (American Farmer, January 1847, p. 211).

A further problem was the lack of control over the use of names. Advertisements for Okra-Twin-Alvarado warned about substitutions. "We are aware that many impositions were practiced last season in the sale of cotton seed purporting to be genuine Alvarado or Okra Seed" (Southern Banner, 9 November 1839, p. 3). Unsatisfactory results from growing Okra were easily attributed to the planters' use of bargain seed of spurious character, seed which sold for $\$ 2$, "while $\$ 5$ is the price of a quart of the genuine seed" (Southern Agriculturist, November 1839, p. 615). The promoters of Mastodon loudly accused counterfeiters of infringing on their product. As early as December 1845, Richard Abbey printed advertisements under the head: "Mastodon Seed-Caution," carrying the text: "I hold myself responsible for the purity or genuineness of no Mastodon Cotton Seed unless sold by myself, or my agents" (Mississippi 
Free Trader, 9 December 1845, p. 1). In early 1846, Abbey's hometown paper, the Yazoo City Whig (9 January 1846, p. 2), trumpeted "Look Out for Counterfeits!!!" Richard Abbey followed up with a "Note to Planters" directly charging the New Orleans' firm Ringgold and Ferriday with selling "spurious" Mastodon seed (Mississippi Free Trader, 12 February 1846 , p. 1). Not only were they stealing his sales, but they were harming Mastodon's reputation.

In the autumn of 1846, Richard Abbey complained in the widely-read periodical Southern Cultivator of the production of "vast quantities of mixed seed." In addition, "extensive frauds have been committed by the sale of quite different kinds of seed as 'Mastodon.' A large commission house in New Orleans has been extensively engaged in this business, and many parts of the country have become flooded with spurious seed" (Southern Cultivator, September 1846, p. 141). Responding to planters' letters, M. Ellis Abbey echoed the charges of fraud: "thousands of bushels were purchased in Mobile and New Orleans for Mastodon Cotton, which had none of the characteristics of the genuine." He opined that sales of bogus seed exceeded that of the genuine. Dishonest vendors "have not scrupled to post up conspicuously flaming bills assuring the public that they have Abbey's Mastodon seed, and profess to have obtained certificates of the fact" (American Farmer, January 1847, p. 211). The brothers claimed to offer genuine seed with the Abbey name on each sack sold through a network of authorized distributors.

There were also alleged examples of breeders selling existing seeds under new names to differentiate their products. Charges of this practice were widespread in the seed wars of the late 1840 s and early 1850 s. In these wars, a select group of breeders who offered steady supplies of improved seed priced at small premia attacked the one-shot introducers such as seedsman G. D. Mitchell. Philips (1855b, p. 225) said of the "Cluster" variety, it is "known now by as many names as there are persons who desire to make money by selling seed." The prevalence of this practice suggests the late-antebellum marketplace was receptive to innovationsnote that Mitchell was not charged with selling his old seed under the name of someone's else improved seed, but with buying someone else's new, improved seed and selling it as his own newer superior creation.

One way to raise one's reputation, both relatively and absolutely, was to point out the sins of others. Much of the agricultural reform literature was devoted to criticism as well as praise. Attacks were especially sharp against those boosters whose promises were too good to be true. Their false claims inhibited true improvement. Thus, in addition to lauding the perseverance and modesty of Henry W. Vick, Martin W. Philips chided 
the activities of others so as far as the southern code of honor among gentlemen (and libel laws) would permit. Vick (1851, p. 129) claimed he was driven by a desire to improve cotton "as far as our climate and soil permit." "No thought of profit, either from increase or quality of crop, or sale of seed" instigated his efforts. He wrote: "I have paid more money for cotton seed, than I received, and have given away more than I have sold." Philips repeatedly chastised Richard Abbey, the promoter of Mastodon. Philips (1849, p. 170) also sharply criticized G. D. Mitchell in print for introducing his Pomegranate variety, which Philips thought was just Hogan or Banana under a new name. In reply, Mitchell (1850, p. 8 ) accused Philips of slander and dishonesty. The two attempted to settle their difference through an exchange of visits. But the dispute would not die as Philips (1850a, 1850b, 1850c, 1851a, 1851b) and fellow reformers continued to deprecate Mitchell and his seed. Mitchell would not back down either. He denied committing any deception, stated that he sold the seed by specimen, and claimed that all his Georgia customers "were entirely satisfied" (Southern Cultivator, August 1852, p. 245). He said no one was harmed and charged Philips for being an impertinent intermeddler in others' affairs. Such controversies generated free publicity and further opportunities to hawk one's wares (Southern Cultivator, June 1851, p. 86).

The agricultural reformers of the antebellum South puzzled over how best to police the cotton seed market. The reformers argued that innovative breeders should share in the productivity advance they created and that high prices for newly discovered or developed seed could well be justified. They did not seek to deny anyone the ability to sell their seed at any price and under any name they choose. Yet they counseled that high prices limited diffusion and that the proliferation of names and the unwarranted claims slowed the cause of improvement. Such practices harmed the innovative breeders and their risk-taking clientele. The repeated examples of humbugs empowered the conservative "good enough" farmers and their slightly more adventurous "show me" colleagues to resist change (see Albany Patriot, 17 January 1851, p. 2). The reformers sought through ridicule and embarrassment to exclude from the ranks of honored improvers those seed sellers who made bogus claims, marketed bad seed, or renamed seed from existing varieties to garner premium prices. The reformers advocated devising unbiased means to test the seed and hold the results up against the proponents' claims (Farrer 1853, p. 108). No one advocated for IPRs.

Many historical accounts concerning the operation of the antebellum cotton seed market are decidedly skeptical. The treatment by Ulrich B. 
Phillips (with two "l"s) in American Negro Slavery (1918, pp. 222-23) is representative. ${ }^{10}$ After noting the surprising success of the early Mexican cotton, Phillips focused on the excesses of the later years - the proliferation of new introductions accompanied by great fanfares of publicity, the very high prices at the IPO and then their collapse shortly thereafter, and the subsequent wave of accusations of fraud and humbuggery. Phillips contrasted the typical planters who passed along his improved seed freely to friends with the flamboyant and less reputable seed promoters. Tellingly, his prime example of the latter was Martin W. Philips. Ulrich B. Phillips' praises of the early rounds of Mexican hybrid cotton was well placed, but his dismissal of later innovations missed the mark. Olmstead and Rhode (2008a, 2008b) document the upward march in picking productivity continued into the early 1860 s.

Martin W. Philips (with one "l") at times adopted a similar scornful tone, but he drew the lines far differently. He viewed himself, Vick, and Jones as the true friends of progress in the cotton sector, truer than the conservative planters who sold lint but would not market their better seed and far truer than seed mongers such as Richard Abbey and G. C. Mitchell. Despite imperfections in the antebellum cotton seed market, Martin W. Philips noted much "good has been done" (Southern Cultivator, July 1848 , p. 101). Philips further said "Large prices induce attention to be directed to the production of choice seed." While "all can improve," they could not "all improve seed as cheap as they can buy... the man who can sell $\$ 500$ or $\$ 1,000$ worth, can bear the extra labor and expense" (quotes from a letter reprinted in Turner $(1857$, p. 99)). They could easily be justified by productivity enhancements. In a letter in the 1849 Annual Report of the U.S. Commissioner of Patents (p. 151), Philips wrote: "admit all this humbuggery, and that the U.S. lost $\$ 100,000$ by it, and a few men pocketed the same-yet, there has been and will be improvements that will enhance the value of cotton estates millions of dollars...." And if the antebellum cotton seed market suffered from problems, it was from too many new cottons, not too few.

\section{MODELING THE COTTON SEED MARKET}

Contemporaries often criticized the operation of the antebellum cotton seed market because the new varieties' high IPO prices soon collapsed so sharply. It was as if the gullible public, caught up in the excitement

\footnotetext{
${ }^{10}$ Baptist (2016, p. 43) expresses similar skepticism of claims about the value of improved cotton seed.
} 
and speculative environment surrounding the new discovery, paid too much for the seed and then learned it was a humbug. But this pattern of initially high, then sharply declining prices is precisely what would be expected if the new productivity-enhancing varieties were released and replicated at a finite rate of multiplication under a regime without IPRs. One might predict that an innovative breeder would seek a new discovery, perhaps build up supplies under one's own control, and then recoup the investment by engaging in a one-time release of the seed at a high initial price. Purchasers could expand supplies of the new seed for their own use and to sell to others. As the seed multiplied, prices would drop sharply. But the breeder would capture at least part of the value of the productivity enhancements and of the capability of the seed to reproduce itself.

Such a process of innovation and diffusion, under circumstances specified by Boldrin and Levine (2008), might well be more efficient than one proceeding under a strict regime of IPRs. The duration of the monopoly will depend on the rate of multiplication rather than legislative fiat. Boldrin and Levine argue that the standard justification for establishing monopoly rights in intellectual property is that invention involves high fixed costs, and imitation is virtually free. In such an environment, innovators could not appropriate sufficient returns to cover the cost of their investments without IPRs. But Boldrin and Levine assert that in many cases, the situation is reversed: invention is cheap, and copying is difficult. The invention side would hold for cotton if the new varieties were discovered as a result of learning by doing-if, while growing their crops, planters remained on the look-out for exceptionally productive individual plants and saved their seed. It would also hold if "invention" involved importing existing varieties from abroad. The copying side would hold if, due to the potential for cross-pollination, replicating a sufficient supply of pure seed from a small initial purchase was difficult.

It will enhance our understanding to sketch out a simple model of the cotton seed market. The market for cotton seed is special because lint is the main product, and seed is a byproduct. Suppose a breeder starts with a monopoly over a supply of $\mathbf{S}$ bushels of a new improved seed that increases the unit value of lint by $\mathbf{v}$ percent over the old seed. That is, given the price of cotton lint is $\mathbf{P}_{\mathbf{L}}$ from the old seed, it will be $(\mathbf{1}+\mathbf{v}) \mathbf{P}_{\mathbf{L}}$ from the new seed. ${ }^{11}$

\footnotetext{
${ }^{11}$ The outcome of the model will not fundamentally change if instead of assuming $\mathrm{P}_{\mathrm{L}, \mathrm{t}}^{\mathrm{N}}=$ $(1+\mathrm{v}) \mathrm{P}_{\mathrm{L}}$, one assumed $\mathrm{P}^{\mathrm{N}}{ }_{\mathrm{L}, \mathrm{t}}=\mathrm{P}_{\mathrm{L}}{ }^{\mathrm{g}} \mathrm{g}\left(\mathrm{Q}_{\mathrm{L}, \mathrm{t}}^{\mathrm{N}} / \mathrm{Q}_{\mathrm{L}}\right)$ where $\mathrm{g}$ ' $<0$. The new seed will be in surfeit when $g\left(Q_{L}^{N} / Q_{L}\right)=1$. Modeling demand for lint from the new variety with a function such as $\mathrm{P}_{\mathrm{L}, \mathrm{t}}^{\mathrm{N}}=\beta\left(\mathrm{Q}_{\mathrm{L}, \mathrm{t}}^{\mathrm{N}}\right)^{-6}$ implies the price of seed will fall even faster as $\varnothing$ increases.
} 
Suppose the unit value of old seed is $\mathbf{P}_{\mathbf{S}}$, which may reflect its value for fertilizer, animal feed, or other uses. Suppose the production technology is otherwise the same-farmers plant " $b$ " bushels of seed per acre, expend $\mathbf{C}$ for other costs, and harvest as a joint product of " $y$ " pounds of lint and $\mathbf{m} * \mathbf{b}$ bushels of seed, where " $\mathbf{m}$ " is the reproduction rate of seed. ${ }^{12}$ Let land be of uniform quality, and the total acreage devoted to cotton be fixed at A. It would obviously be possible for a new variety to alter yields or changes per acre cost, but one can gain insight into the expected path of seed prices by examining the case where the new seed raises quality. The supply of the new seed is initially limited but grows at the rate $\mathbf{m}$. The market price of this new seed, $\mathbf{P}_{\mathrm{N}, \mathrm{t}}$, will depend on whether the stock is in deficit or surfeit of the quantity required to plant the acreage $\mathbf{A}$.

Consider the decision to adopt the seed by a planter. The planter could stick with the old technology, spending $\mathbf{b} \mathbf{P}_{\mathbf{s}}$ for seed and $\mathbf{C}$ for other expenses and then earning $\mathbf{y} \mathbf{P}_{\mathbf{L}}$ for the lint and $\mathbf{m b} \mathbf{P}_{\mathbf{S}}$ for the seed. Alternatively, the planter could adopt the new technology, spending $\mathbf{b} \mathbf{P}_{\mathrm{N}, \mathrm{t}}$ for seed and $\mathbf{C}$ for other expenses and then earning $(1+\mathrm{v}) \mathrm{yP}_{\mathrm{L}}$ for the lint and $\mathrm{mbP}_{\mathrm{N}, \mathrm{t}+1}$ for the new seed. Denote the one-period discount factor as $\mathbf{d} \leq 1$. The planter's breakeven point will occur where the difference between the new and old seed equals the discounted value of the improved lint and additional seeds:

$$
\mathrm{P}_{\mathrm{N}, \mathrm{t}}=\mathrm{P}_{\mathrm{S}}+\mathrm{d}\left[\mathrm{vyP}_{\mathrm{L}} / \mathrm{b}+\left(\mathrm{P}_{\mathrm{N}, \mathrm{t}+1}-\mathrm{P}_{\mathrm{S}}\right) \mathrm{m}\right] .
$$

A planter will adopt the new seed for any price at this level or below.

Now consider the year $\mathrm{t}=\mathrm{T}$ when $\mathrm{Sm}^{\mathrm{T}} \geq \mathrm{bA}>\mathrm{Sm}^{\mathrm{T}-1}$. This is the first year when the supply of the new seed is sufficient to plant the entire cotton acreage. Given the surfeit of new seed in the hands of planters, new seed will be worth the same as old seed, $\mathrm{P}_{\mathrm{N}, \mathrm{t}}=\mathrm{P}_{\mathrm{S}}$, in any year $\mathrm{t}>$ $\log (\mathrm{bA} / \mathrm{S}) / \log (\mathrm{m})$. Now consider year $\mathrm{T}-1$. There is $\mathrm{Sm}^{\mathrm{T}-1}$ seed which is sufficient to plant $\mathrm{Sm}^{\mathrm{T}-1} / \mathrm{b}$ acreage. The unit (present) value of seed in $\mathrm{T}-$ 1 is then $\mathrm{P}_{\mathrm{N}, \mathrm{T}-1}=\mathrm{P}_{\mathrm{S}}+\mathrm{dvy}_{\mathrm{L}} / \mathrm{b}$. The seed's premium is the discount value of the higher-quality lint it yields. Now consider $\mathrm{T}-2$. There is $\mathrm{Sm}^{\mathrm{T}-2}$ seed with unit value of seed, $\mathrm{P}_{\mathrm{N}, \mathrm{T}-2}=\mathrm{P}_{\mathrm{S}}+(1+\mathrm{dm}) \mathrm{dvy}_{\mathrm{L}} / \mathrm{b}$. Its premium is the discount value of the higher-quality lint it yields plus the discount

\footnotetext{
${ }^{12}$ For the late antebellum era, it was conventional to think of unginned seed cotton as turning out 2 pounds of seed for every 1 pound of lint. Let us call this ratio, $t$, and also let $w$ represent the number of pounds of seed per bushel. Then the reproduction or multiplication rate of seed, " $m$," can be expressed as $\mathrm{m}=\mathrm{yt} / \mathrm{wb}$, that is, (lb of lint output per acre) * (lb of seed per lb of lint $) /(\mathrm{lb}$ of seed per bushel) * (bushels seed applied per acre.)
} 
value of superior seed for planting in $\mathrm{T}-1$. By extending this reasoning, one sees the unit value of seed in year $T-\tau$, for $\tau \geq 1$, is:

$$
\mathrm{P}_{\mathrm{N}, \mathrm{T}-\tau}=\mathrm{P}_{\mathrm{S}}+\left(\sum_{\mathrm{t}=0}^{\tau-1}(\mathrm{dm})^{\mathrm{t}}\right)\left(\mathrm{dvy}_{\mathrm{L}} / \mathrm{b}\right)
$$

In the years prior to $\mathrm{T}$, the premium will decline by more than $\mathrm{dm}$ per year. ${ }^{13}$

Figure 3 graphically displays the relationship between the supply of seed and the acreage planted. The upper panel charts how the increase in the supply of improved seed raises the value of lint cotton produced. The lower panel plots out the demand function for new seed, tracing out the market prices associated with each quantity. After release, the supply of seed is perfectly inelastic (with respect to its own price) and grows exogenously at rate $\mathrm{m}$ per year. (Changing the reproduction rate, "m," has two offsetting effects on the initial value of the stock: it increases the $\mathrm{dm}$ term and decreases the $\mathrm{T}$ term.) The quantities may be related back to the temporal analysis discussed earlier. The period of surfeit is associated with quantities supplied above bA. Quantities in the interval (bA/m, bA) are associated with a crop season one year before seed surfeit. Quantities in the interval $\left(\mathrm{bA} / \mathrm{m}^{2}, \mathrm{bA} / \mathrm{m}\right)$ are associated with a crop season two years prior. Those, such as the $\mathrm{S}_{-3}$ in the diagram, which is in the interval (bA/ $\mathrm{m}^{3}, \mathrm{bA} / \mathrm{m}^{2}$ ) are three years prior; and so on.

The initial value of the seed stock to the breeder at release in year 0 is

$$
\mathrm{S}_{0} \mathrm{P}_{\mathrm{N}, 0}=\mathrm{S}_{0} \mathrm{P}_{\mathrm{S}}+\left(\sum_{\mathrm{t}=0}^{\mathrm{T}-1}(\mathrm{dm})^{\mathrm{t}}\right) \mathrm{S}_{0} \mathrm{dvy} \mathrm{P}_{\mathrm{L}} / \mathrm{b}
$$

The breeder appropriates all of the returns generated by the new seed during the period that it is in deficit and none generated thereafter. If breeding the new seed is costly, this sum sets the bar on what is worth pursuing under the regime without IPRs.

The value of making discoveries would be higher if the breeder could, through the operation of IPRs, securely control access to the seed. Compare the outcome discussed previously to a regime where the breeder maintains full property rights over the seed and rents its services to the planters. (How the IPRs could be enforced and replication prevented is not addressed; the IPRs are treated here as infinitely lived.) The seed will not have a price; instead, the seed services will be rented for $\mathrm{dvyP}_{\mathrm{L}} / \mathrm{b}$ per

\footnotetext{
${ }^{13}$ Prices declining at a geometric rate of $(\mathrm{dm})$ per year serve as a benchmark case. Consider a stock that split $\mathrm{m}$-fold per year with each existing share in year $\mathrm{T}$ guaranteed to be repurchased for price $\mathrm{P}$. The net present value of a share in year $\mathrm{k}$ is $(\mathrm{dm})^{\mathrm{T}-\mathrm{k}} \mathrm{P}$. The seed models differ from this benchmark case because there are other inputs (specifically land) besides seed into production. See the Online Appendix model.
} 
Panel A. Relationship between Seed Supplies and Increase Value on Lint Production

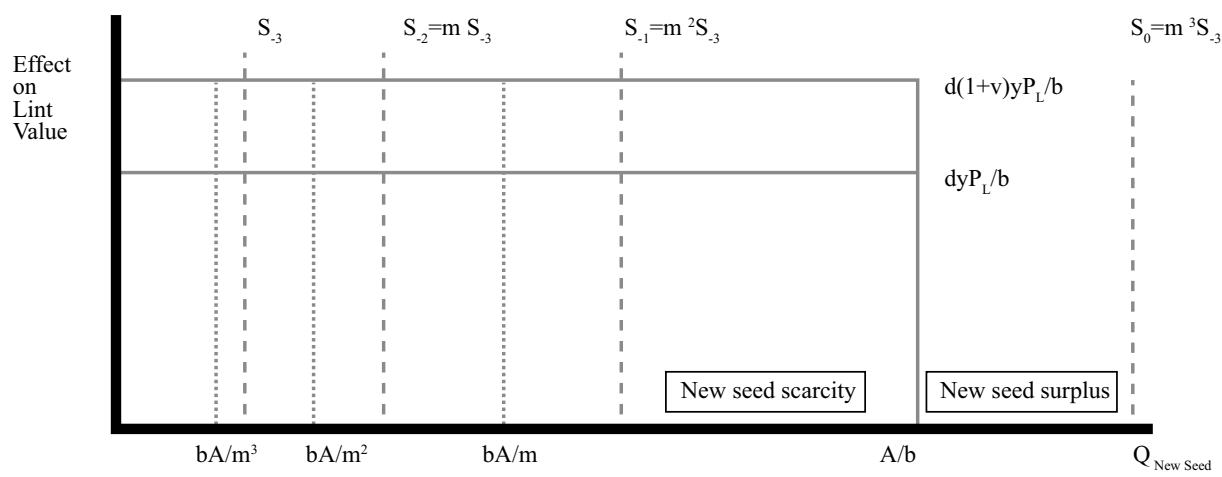

Panel B. Demand Function for New Seed

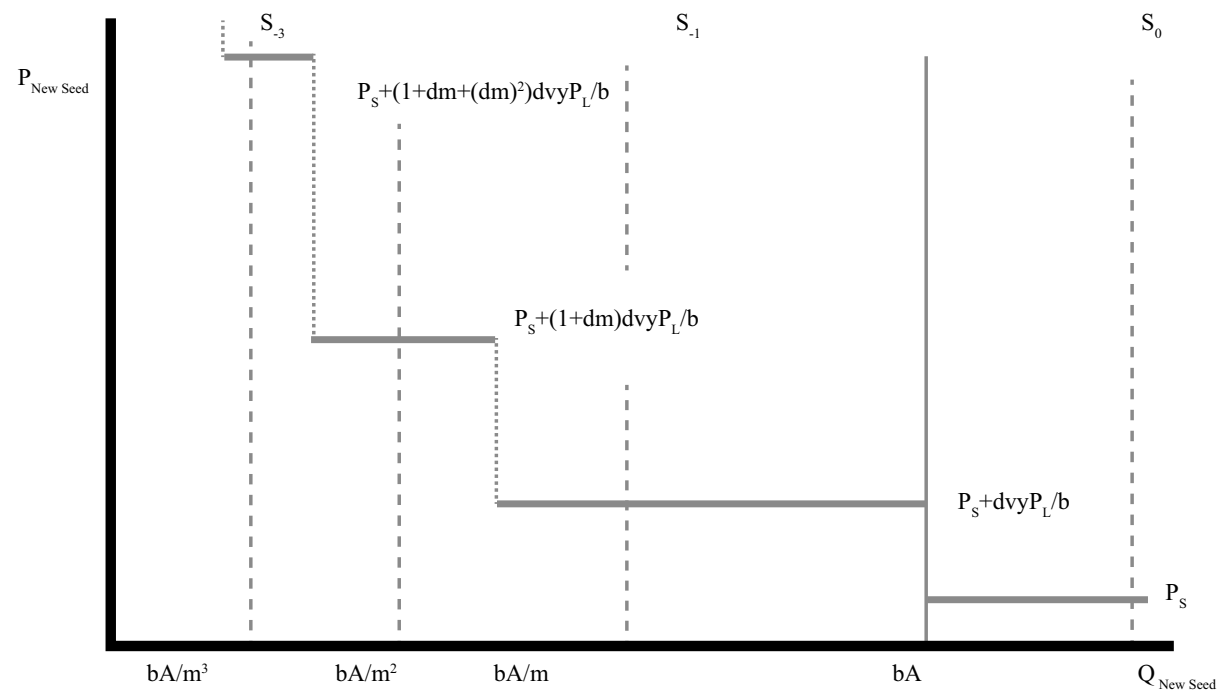

FIGURE 3

THE MARKET FOR NEW SEED

Source: Author's illustration.

unit of seed up to $\mathrm{T}$ and then for $\mathrm{dvyP}_{\mathrm{L}}$ per acre in the period after the seed stock is sufficient to plant the entire acreage. The net present value of the flow of rental payments in a year 0 will be:

$$
\mathrm{NPV}_{0}=\left(\sum_{\mathrm{t}=0}^{\mathrm{T}-1}(\mathrm{dm})^{\mathrm{t}}\right) \mathrm{S}_{0} / \mathrm{b}+\mathrm{A}\left(\sum_{\mathrm{i}=\mathrm{T}}^{\infty} \mathrm{d}^{\mathrm{t}}\right)\left(\mathrm{dvyP}_{\mathrm{L}}\right)<\mathrm{A}\left(\mathrm{dvyP}_{\mathrm{L}}\right) /(1-\mathrm{d})
$$

The first term is the equivalent to $\left(\mathrm{P}_{\mathrm{N}, 0}-\mathrm{P}_{\mathrm{S}}\right) \mathrm{S}_{0}$. The flow of payments after $T$ raises the NPV from the full IPR-rental regime above the NPV of the initial seed to the breeder in the sales regimes. This would support 
a wider range of costly investments in seed breeding. One further note about the value of the stock as represented in Equation (3): this market provides incentives to release as soon as possible. The discounting and price declines punish holding unplanted seed to the next year, and unless the breeder can multiply pure seed faster than the planters, the market provides incentives to release the initial seed immediately.

The model described previously of a seed market without IPRs makes strong assumptions about the demand structure and the inelasticity and exogenous growth of the supply of seed after release. It fixes both the total acreage and value of the added quality from the new seed. Perhaps more heroically, it assumes the purchasers know quality advantages and price path with certainty. The price dynamics work through relaxing supply constraints as opposed to any form of strategic interaction or learning about quality. The industrial structure of the breeding sector does not come into play until the period of surfeit when competition reduces the price premium to zero. Introducing a second breeder with a supply $\mathrm{S}_{\mathrm{A}}$ of seed that is equal (or better) quality would alter the model by hastening the year $\mathrm{T}$ of seed surfeit. If the second seed was better $\left(\mathrm{v}_{\mathrm{A}}>\mathrm{v}\right)$, it would continue to displace the first after the year $\mathrm{T}$ was reached. If the introduction of the newer improved seed were a probabilistic event, the initial price of the new seed will be lower, the greater the likelihood of its arrival. Alternatively, allowing for the possibility that the improved seed reverted to become like the regular seed ( $v=0$ at some $t)$, that is, the improved seed proved to be a humbug, would not fundamentally alter the price path. See the Online Appendix for extensions of the model in these directions.

Using the available evidence, we can gain a sense of the magnitudes involved circa 1850 . First, consider the extra annual revenue, $\operatorname{vyP}_{L} / b$, generated by a unit of improved seed. Taking the yield as $200 \mathrm{lb}$ of lint per acre, the price of lint as $\$ 0.10 / \mathrm{lb}$, and $\mathrm{b}$ as 2.5 bushels $(75 \mathrm{lb})$ of seed per acre, then a new variety that was 5 percent better $(\mathrm{v}=0.05)$ would generate additional annual lint revenue of about $\$ 0.40$ per bushel of seed. Next, consider the rate of price declines. If $m=5.33$ (as suggested by the numbers in the introduction) and $d=0.93$, then $d m=4.96$. Given these benchmark parameters, the premium on seed $\left(\mathrm{P}_{\mathrm{T}-\tau}-\mathrm{P}_{\mathrm{S}}\right)$ of a variety that was 5 percent improvement would have the following path:

$\begin{array}{llllllll}\text { Years before Surfeit } & \mathrm{T} & \mathrm{T}-1 & \mathrm{~T}-2 & \mathrm{~T}-3 & \mathrm{~T}-4 & \mathrm{~T}-5 & \mathrm{~T}-6 \\ \text { Premium in } \$ & 0 & 0.37 & 2.22 & 11.37 & 56.8 & 282 & 1399\end{array}$

The premium would vary in proportion to percentage increase in productivity; a seed offering a 10 percent gain would have double the premium 
listed earlier. The high value of seeds in the early period $(T-6)$ suggests that even without IPRs, many breeding opportunities would have been profitable - those growing cotton certainly had strong incentives to be on the lookout for outstanding performers in the fields.

More generally, the model predicts very high initial prices for seed offering modest productivity enhancements, and then very rapid price declines. Actual IPO prices do not typically reach the levels predicted by the model based on the productivity claims. It is likely that uncertainty over quality tempered initial demand.

It is possible to extend the model in several directions. One may wish to account for the fact that the new variety is advantageous only in a selected market niche. The relevant area to be planted is smaller, and the $\mathrm{T}$ required the seed to plant this area is shorter for a given initial stock of seed. An introductory period of experimentation may be required to determine how large this area is. It is also possible the new variety is a humbug, either genetically unstable or unsuitable for any market niche. Again, an introductory period of experimentation may reveal these features. In this period, prices will be in flux and may fall sharply on bad news. What the model shows is that even with complete information, price declines are to be expected as the seed replicates at a finite rate.

\section{PRICE DATA FROM NEWSPAPER ADVERTISEMENTS}

We now turn to investigate the actual price path of cotton varieties, based on a dataset assembled from advertisements in antebellum newspapers and agricultural journals. As noted previously, such advertisements were common in southern periodicals from the 1830 s on. In a small fraction (maybe one-tenth) of ads, the supplier listed a price. Assembling a sample from advertisements creates biases against observing very low prices. The expected profits from the sales had to justify the expense of advertising, and there is no evidence that merchants treated cotton seed as a loss-leader to generate other trade.

I constructed a sample of 526 price observations from 124 different newspapers and agricultural journals covering a territory from Virginia to Texas over the period from 1835 to 1862 . I collected all advertisements including explicit prices per specified qualities found in a systematic search using the key words "Cottonseed" and "Cotton Seed" in all digital databases available to me. The searched databases were extensive and included Readex Early American Newspapers, Newsbank's GenealogyBank, the Library of Congress Chronicling America, Gale's $19^{\text {th }}$ Century Newspapers, Ancestry's Newspapers.com, Proquest American 
Periodicals, Proquest Historical Newspapers, Google Historical Newspapers, Access NewspaperArchive, Florida Digital Newspaper Library, Digital Library of Georgia: Historical Newspapers; Louisiana Digital Library, North Carolina Newspaper: DigitalNC; Historical Newspapers of South Carolina; and The Portal to Texas History: Texas Digital Newspaper Program. The creation of the online Chronicling America project is now complete. ${ }^{14} \mathrm{~A}$ recent refreshed search of advertisements yielded no additions to the samples.

The overall sample covers 74 different named varieties of upland cotton. The unit of observation is a variety listed in an advertisement in a specific publication in a specific crop year, ending in June. The advertisements typically ran over multiple issues of the periodical, but if the text remained unchanged in that source, it counted only once per variety listed. If the supplier published a revision - for example, to change the prices over the course of the season-the revision counted as a separate observation. If the supplier placed a similar advertisement in a different periodical, it counted as a separate observation. If the advertisement listed prices for multiple varieties, each was counted as an observation. In some instances, agricultural journalists offered seed in the columns of their publications. Such price quotes were included.

I was able to link 48 varieties to information on the dates of introduction, as reported in Ware (1950), Duggar (1907), Tyler (1910), and newspaper sources. Assigning a date of release can be tricky. There is often a difference between when the seed was discovered or imported, when it was made available to a selected few for testing and multiplication, and when it was released for sale to the general public. I adopted a standard close to the date of release. There were advertisements containing prices for 26 additional named varieties, which could not be linked. These were not included in the sample. Their prices were roughly on par with varieties out for five years. The regression analysis will be conducted using a less structured form - dummy variables for years since release - and using a more specified functional form - the log of years since releasewhich smooths over gaps in the data.

Table 1 summarizes the path of mean nominal price per bushel after an introduction for selected important varieties. As contemporaries noted, for many high-profile varieties such as Twin/Okra, Hogan, Banana, and Pomegranate, prices shortly after introduction were very high, between $\$ 100$ and $\$ 1000$ per bushel in an era where common laborers earned

${ }^{14}$ I also reviewed selected newspapers at selected microfilmed newspapers from Harvard University Library, Yale University Library, the Library of Congress, and the Mississippi Department of Archives and History. 


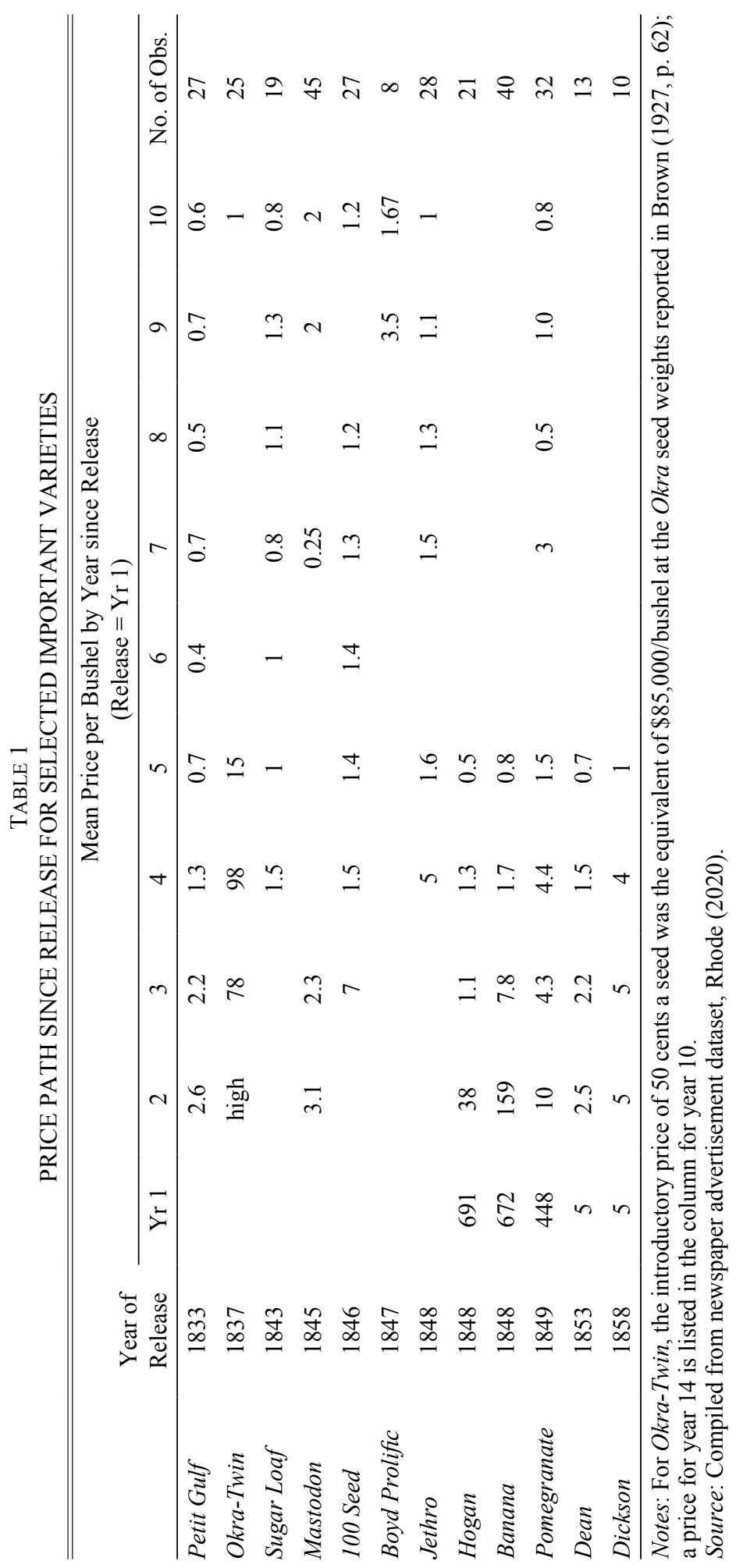




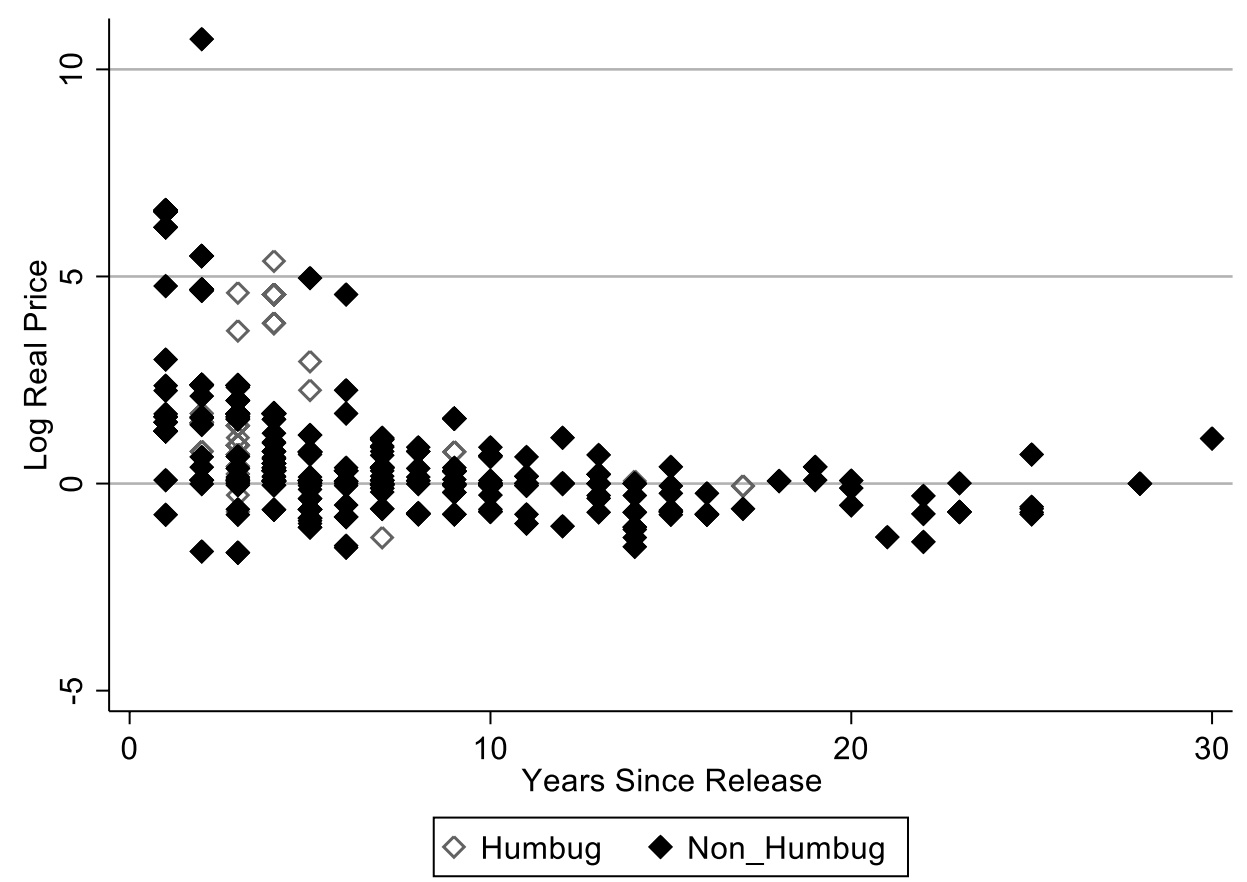

FIGURE 4

SCATTERPLOT OF LOG REAL PRICES VERSUS NUMBER OF YEARS SINCE RELEASE

Notes: Price path without controls; Okra/Twin and Mastodon coded as Humbugs. Source: Compiled from Newspaper Advertisement Database, Rhode (2020).

about one dollar per day. Prices subsequently fell substantially, with few varieties commanding more than much $\$ 1$ per bushel after five years. Boyd's Prolific is an exception. There are no price quotes available in the early years, but the variety continued to sell for more than $\$ 1$ per bushel ten years out. This variety, which became widely available in the early 1850 s, was a selection or refinement of the original "accidental stalk" that Mr. Boyd discovered in a field of Petit Gulf in 1845. Boyd's popularity grew slowly after its introduction in 1847 . The contrast in price paths between Mastodon and 100 Seed, both hitting the market circa 184647 , is not as great as suggested in the traditional accounts marking the former as a speculative humbug and the latter as the real deal. But the high initial prices for the late 1840 cluster-type cotton-Hogan, Banana, and Pomegranate - do stand out.

Figure 4 presents a scatterplot of log of real prices against time since release. The negative relationship between prices and years since release is evident. Unlike stories about the Dutch tulip mania of the seventeenth century, the seeds of important southern cotton varieties in the 
mid-nineteenth century rarely experienced a phase of rising prices after the IPO (Garber 2000, pp. 49-59, 66). ${ }^{15}$ The plotted data include different varieties but no other controls.

The regression analysis adds controls for such differences by including variety fixed effects as well as crop year effects and other potential confounding variables. This analysis investigates two specifications:

$$
\begin{aligned}
& \ln \mathrm{P}_{\mathrm{i}}=\sum_{\mathrm{j}=1}^{7} \text { Indicator_year_since_release }_{\mathrm{i}}+\mathrm{X}^{\prime} \boldsymbol{\beta}+\boldsymbol{\delta}^{*} \text { crop_year } \\
& + \text { Variety }_{\mathrm{j}}+\boldsymbol{\varepsilon}_{\mathrm{i}} \\
& \ln \mathrm{P}_{\mathrm{i}}=\boldsymbol{\alpha} \operatorname{Ln}\left(\text { years_out }_{\mathrm{j}}\right)+\mathrm{X}^{\prime} \boldsymbol{\beta}+\text { Variety }_{\mathrm{j}}+\boldsymbol{\varepsilon}_{\mathrm{i}} .
\end{aligned}
$$

The unit of observation is the price, $\mathrm{P}_{\mathrm{i}}$, in a newspaper advertisement, of variety $j$ in year $t$. The panel is unbalanced with a varying number of observations for a given variety, $\mathrm{j}$, in year, t. In the first specification, shown in Equation (5), time in the market for the variety is measured by indicators for the first seven years since release (years 8 plus is the omitted category). In the second specification, shown in Equation (6), time in the market is measured by a continuous variable, the log of years out, where years_out equals 1 for newly-released varieties. Both specifications include a variety of fixed effects. The first specification includes a linear crop year trend, which is identified off the omitted years-sincerelease category; the second specification does not admit a year trend. See Table 2, Panel A for summary statistics.

The variables in $\mathrm{X}$ are a set of controls. They include indicator variables (a) for the advertisement being in a newspaper in the Old South, reflecting greater distance from the center of seed production and innovation; (b) for the seed lot size being small (less than a bushel) and likely offered at a premium; and (c) for the seed offer being of second quality, as specified in the advertisement, for example, as "gin-run." The controls are included to enhance the comparability of the price quotes across different newspaper advertisements. The expectations are that the Old South and small lot coefficients will be positive (higher prices), and the second-quality coefficient will be negative (lower prices).

I also constructed two variables - humbug and "branded" - to breakdown the sample as desired. Humbugs are those varieties-Okra/Twin

\footnotetext{
${ }^{15}$ The price of Mastodon seed did rise over in the winter of 1845-46. There is some indication that Twin-Okra prices rose in the late 1830s as the variety gained popularity, but the information available is too scanty to draw a firm conclusion. Sugar Loaf, an early cluster type, represents another variant, where the near-immediate introduction of rival varieties paced competitive pressure of prices.
} 


\section{Cottonseed Markets in the Antebellum American South 229}

TABLE 2

EMPIRICAL RESULTS

\begin{tabular}{|c|c|c|c|c|c|}
\hline \multicolumn{6}{|c|}{ A. Summary Statistics } \\
\hline & Obs. & Mean & St. Dev. & Min. & Max. \\
\hline Log (Real Price) & 459 & 0.949 & 1.769 & -1.667 & 10.732 \\
\hline Year 1 & 459 & 0.070 & 0.254 & 0 & 1 \\
\hline Year 2 & 459 & 0.111 & 0.314 & 0 & 1 \\
\hline Year 3 & 459 & 0.154 & 0.362 & 0 & 1 \\
\hline Year 4 & 459 & 0.168 & 0.374 & 0 & 1 \\
\hline Year 5 & 459 & 0.094 & 0.292 & 0 & 1 \\
\hline Year 6 & 459 & 0.037 & 0.189 & 0 & 1 \\
\hline Year 7 & 459 & 0.072 & 0.259 & 0 & 1 \\
\hline Log (Years Out) & 459 & 1.577 & 0.782 & 0 & 3.401 \\
\hline Crop_Year & 459 & 1850 & 6.026 & 1834 & 1862 \\
\hline Small_Lot & 459 & 0.046 & 0.210 & 0 & 1 \\
\hline Second_Quality & 459 & 0.039 & 0.194 & 0 & 1 \\
\hline Old_South & 459 & 0.492 & 0.500 & 0 & 1 \\
\hline Branded & 459 & 0.752 & 0.433 & 0 & 1 \\
\hline Humbug & 459 & 0.154 & 0.362 & 0 & 1 \\
\hline
\end{tabular}

B. OLS Regressions

\begin{tabular}{|c|c|c|c|}
\hline \multirow{3}{*}{$\begin{array}{l}\text { Year Indicator } \\
\text { Specifications }\end{array}$} & \multicolumn{3}{|c|}{ Dependent Variable: Log(Real Price) } \\
\hline & 1 & 2 & 3 \\
\hline & Full Sample & Not Humbug & Branded \\
\hline Year 1 & $\begin{array}{c}3.584 \\
{[0.646]}\end{array}$ & $\begin{array}{c}3.538 \\
{[0.689]}\end{array}$ & $\begin{array}{l}4.375 \\
{[0.622]}\end{array}$ \\
\hline Year 2 & $\begin{array}{c}2.470 \\
{[0.411]}\end{array}$ & $\begin{array}{c}2.944 \\
{[0.532]}\end{array}$ & $\begin{array}{c}2.947 \\
{[0.480]}\end{array}$ \\
\hline Year 3 & $\begin{array}{c}1.264 \\
{[0.272]}\end{array}$ & $\begin{array}{c}1.481 \\
{[0.270]}\end{array}$ & $\begin{array}{c}1.583 \\
{[0.339]}\end{array}$ \\
\hline Year 4 & $\begin{array}{c}0.609 \\
{[0.237]}\end{array}$ & $\begin{array}{c}0.597 \\
{[0.211]}\end{array}$ & $\begin{array}{c}0.789 \\
{[0.275]}\end{array}$ \\
\hline Year 5 & $\begin{array}{c}0.149 \\
{[0.188]}\end{array}$ & $\begin{array}{c}0.328 \\
{[0.174]}\end{array}$ & $\begin{array}{c}0.187 \\
{[0.239]}\end{array}$ \\
\hline Year 6 & $\begin{array}{c}0.062 \\
{[0.157]}\end{array}$ & $\begin{array}{c}0.227 \\
{[0.143]}\end{array}$ & $\begin{array}{c}0.241 \\
{[0.197]}\end{array}$ \\
\hline Year 7 & $\begin{array}{c}0.131 \\
{[0.157]}\end{array}$ & $\begin{array}{c}0.256 \\
{[0.146]}\end{array}$ & $\begin{array}{c}0.117 \\
{[0.178]}\end{array}$ \\
\hline Crop_Year & $\begin{array}{c}0.018 \\
{[0.012]}\end{array}$ & $\begin{array}{c}0.028 \\
{[0.012]}\end{array}$ & $\begin{array}{c}0.008 \\
{[0.289]}\end{array}$ \\
\hline Small_Lot & $\begin{array}{c}2.164 \\
{[0.467]}\end{array}$ & $\begin{array}{c}2.667 \\
{[0.519]}\end{array}$ & $\begin{array}{l}1.775 \\
{[0.438]}\end{array}$ \\
\hline Second_Quality & $\begin{array}{c}-0.962 \\
{[0.281]}\end{array}$ & $\begin{array}{c}-0.899 \\
{[0.313]}\end{array}$ & $\begin{array}{l}-1.443 \\
{[0.177]}\end{array}$ \\
\hline Old_South & $\begin{array}{c}0.298 \\
{[0.099]}\end{array}$ & $\begin{array}{c}0.093 \\
{[0.102]}\end{array}$ & $\begin{array}{c}0.377 \\
{[0.113]}\end{array}$ \\
\hline Constant & $\begin{array}{l}-34.031 \\
{[22.670]}\end{array}$ & $\begin{array}{l}-51.334 \\
{[21.388]}\end{array}$ & $\begin{array}{l}-15.429 \\
{[53.735]}\end{array}$ \\
\hline Obs. & 458 & 387 & 345 \\
\hline Categories & 43 & 41 & 26 \\
\hline R-squared & 0.782 & 0.783 & 0.778 \\
\hline
\end{tabular}




\begin{tabular}{|c|c|c|c|}
\hline \multicolumn{4}{|l|}{ C. OLS Regressions } \\
\hline \multirow{3}{*}{$\begin{array}{l}\text { Log Year } \\
\text { Specifications }\end{array}$} & \multicolumn{3}{|c|}{ Dependent Variable: $\log ($ Real Price $)$} \\
\hline & 1 & 2 & 3 \\
\hline & Full Sample & Not Humbug & Branded \\
\hline Log (Years Out) & $\begin{array}{c}-1.044 \\
{[0.171]}\end{array}$ & $\begin{array}{l}-1.047 \\
{[0.201]}\end{array}$ & $\begin{array}{l}-1.713 \\
{[0.226]}\end{array}$ \\
\hline Small_Lot & $\begin{array}{c}2.976 \\
{[0.361]}\end{array}$ & $\begin{array}{c}3.490 \\
{[0.322]}\end{array}$ & $\begin{array}{c}2.406 \\
{[0.359]}\end{array}$ \\
\hline Second_Quality & $\begin{array}{l}-1.448 \\
{[0.290]}\end{array}$ & $\begin{array}{l}-1.407 \\
{[0.317]}\end{array}$ & $\begin{array}{l}-1.343 \\
{[0.149]}\end{array}$ \\
\hline Old_South & $\begin{array}{c}0.144 \\
{[0.113]}\end{array}$ & $\begin{array}{l}-0.051 \\
{[0.128]}\end{array}$ & $\begin{array}{c}0.260 \\
{[0.116]}\end{array}$ \\
\hline Constant & $\begin{array}{c}2.443 \\
{[0.311]}\end{array}$ & $\begin{array}{c}2.430 \\
{[0.394]}\end{array}$ & $\begin{array}{c}3.479 \\
{[0.374]}\end{array}$ \\
\hline Obs. & 458 & 387 & 345 \\
\hline Categories & 43 & 41 & 26 \\
\hline R-squared & 0.744 & 0.733 & 0.752 \\
\hline
\end{tabular}

Notes: All regressions include variety fixed effects.

[The numbers in square brackets, [], are robust standard errors.

Source: Compiled from newspaper advertisement dataset, Rhode (2020).

and Mastodon - that contemporaries, rightly-or-wrongly, labeled as such. We can limit the sample to "non-humbugs" when we wish to focus on varieties with untarnished reputations. "Branded" varieties are those introduced to the market with large advertisements - with a height in newspapers column inches exceeding their width or featured in a prominent farm journal such as American Farmer, Southern Cultivator, or the like. The "branded" varieties included many of the seeds receiving the most public attention.

The regressions, shown in Table 2, Panel B, relate the log of the real price to the indicators for the first seven years since release, deflated to 1860 prices from the "MeasuringWorth.com" retail price series. We will use as the benchmark case outcomes where the controls (Small Lot, Second Quality, and Old South) are set to zero, and the Year is at the mean of the sample, 1850. For the full sample (first column), the benchmark prices in the second year were only 32.8 percent of prices in the first year; that is, $\exp (2.470) / \exp (3.584)$. Prices in the third year were 29.9 percent of prices in the second year and 9.8 percent of prices in the first year. Overall, this was a 3.19-fold decline each year. Prices for varieties remaining in the sample stabilized after roughly four years.

The regressions, shown in Table 2, Panel C, use the log of years since release, in place the year indicators and crop year variable. In this 
specification, doubling the time since release reduced benchmark prices by over one-half; $\exp (-1.044 * \ln (2))=0.484$.

One might be concerned that the negative price trajectory was the product of humbugs being discovered and discounted in the market. The second column of Panel B shows results for the same specification in a sample, excluding the two major alleged humbugs (Twin-Okra and Mastodon). The results for the year indicators are in line with those for the full sample, suggesting the negative price trajectory was not driven by the humbugs alone. The price declines remain sharp, though not as sharp as in the full sample. Benchmark prices in the second year were 55.2 percent of prices in the first year; prices in the third year were 23.2 percent of prices in the second year and 12.8 percent of prices in the first year. This was a 2.80 -fold decline each year. The continuous time regression (Panel C) shows declines of comparably large magnitudes as the full sample. In this specification, doubling the time since release reduced prices to 48.3 percent of the base level.

The third column restricts the analysis to "branded" varieties, those varieties introduced with a substantial investment in publicity. Prices for "branded" varieties started considerably higher than non-branded varieties but fell more rapidly. (In results not shown, "branded" varieties sold for 70 percent more (coeff. $=0.696$, s.e. 0.148 ) than non-branded varieties in regressions including the same set of controls.) In Panel B, prices in the second year were 24.0 percent of prices in the first year; prices in the third year were 25.6 percent of prices in the second year and 6.1 percent of prices in the first year. This was a 4.05 -fold decline each year. The continuous time regression (Panel C) shows declines of larger magnitudes than in the full sample. In this specification, doubling the time since release reduced prices to 30.5 of the base level.

The patterns revealed in the newspaper quotes-high IPO prices for non-humbug varieties and for branded varieties - followed by rapid declines in the years following release are consistent with the results in the modeling section. And as noted previously, the high IPO prices provided significant (if not fully optimal) incentives for seed suppliers to introduce new and improved cotton seed in the absence of IPRs.

\section{CONCLUSION}

This investigation demonstrates the existence of an active market for new varieties of cotton seed in the antebellum American South in the complete absence of IPRs. It collects extensive evidence from newspaper advertisements to chart the price path of the new varieties. At the time 
of introduction, prices were often very high but in subsequent seasons rapidly declined from the IPO level. These patterns can be rationalized in terms of a market model given the potential of improved seed to increase operating returns and feasible finite rates of seed multiplication. The observed initial prices were also sufficiently high relative to the opportunity cost of labor to provide meaningful incentives to search for and refine improved seed varieties. This study also identifies information problems affecting the antebellum cotton seed market, leading observers to claim too many new varieties were released, not too few.

The historical environment under study differs from the current environment in several important ways. The differences in the opportunities, costs, and regulatory environment affecting plant breeding are especially noteworthy. Under current conditions, the costs in scientific resources and the time required to produce new biotech cultivars are very high. According to a recent CropLife International study, across the 2008-12 period, each new genetically-engineered trait required, on average, an investment of $\$ 136$ million and more than 13 years to develop and commercialize. ${ }^{16}$ The regulatory hurdles associated with testing and certifying genetically-modified organism technologies added significantly to these costs (Kalaitzandonakes, Alston, and Bradford 2007). This regulatory and scientific environment forms the context for the 2013 Supreme Court Bowman v. Monsanto decision raised in the introduction. This environment, obviously, does not hold everywhere and always.

The costs of innovation in the past were not as high as today. Many of the new seed developments were the product of learning by doing or, perhaps better put, learning-by-growing. Astute growers gathered and selected the new seeds from promising plant variants from their fields of growing crops. Many other new seeds were introduced from the outside by travelers and plant explorers. This activity was intentional, costly, and at times illegal. In the late eighteenth and early nineteenth century, nation-states often considered indigenous biological material as part of their patrimony and outlawed its export. Walter Burling's endeavor to smuggle white-seed cotton out of Mexico was one example of a much more wide-spread process of illegal international exchange of genetic material. An additional source of new varieties was systematic breeding. To be successful, new varieties derived from foreign introductions or domestic variations often requiring breeding work to acclimatize them to the local growing environment. Given that cotton had been grown

${ }^{16}$ CropLife International, "The Cost and Time Involved in the Discovery, Development and Authorization of a New Plant Biotechnology Derived Trait," www.croplife.org/ PhillipsMcDougallStudy, examined 28 September 2013. 


\section{Cottonseed Markets in the Antebellum American South 233}

extensively in the American South only since the 1790s, the technical possibilities for discovering new valuable seed varieties may have been especially fruitful. Such differences must be kept clearly in mind before drawing any current-day policy lessons from the operation of the antebellum cotton seed market. Differences in historical settings are also important to understand when applying legal institutions designed in the late eighteenth century, such as the patent system, to modern technologies.

\section{REFERENCES}

Albany [GA] Patriot. Various issues.

American Agriculturist. Various issues.

American Farmer. Various issues.

Baptist, Edward E. (2016). "Toward a Political Economy of Slave Labor: Hands, Whipping-Machines, and Modern Power.” In Slavery's Capitalism: A New History of American Economic Development, edited by Sven Beckert and Seth Rockman, 31-70. Philadelphia: University of Pennsylvania Press.

Boldrin, Michele, and David K. Levine. Against Intellectual Monopoly. New York: Cambridge University Press, 2008.

Bonner, James C. "Genesis of Agricultural Reform in the Cotton Belt." Journal of Southern History 9, no. 2 (1943): 475-500.

Brockett, Linus Pierpott. The Silk Industry: A History, Prepared for the Centennial Exposition. New York: Silk Association of America, 1876.

Brown, Harry B. Cotton: History, Species, Varieties, Morphology, Breeding, Culture, Diseases, Marketing, and Uses. New York: McGraw-Hill.

Cabral, Luis M. B. "The Economics of Trust and Reputation: A Primer," 2005. Available at http://pages.stern.nyu.edu/ lcabral/reputation/Reputation_June05.pdf.

Calhoun, John C., and Clyde N. Wilson, eds. Papers of John C. Calhoun Vol. 12. Columbia, SC: University of South Carolina Press, 1995.

Coclanis, Peter A. The Shadow of a Dream: Economic Life and Death in the South Carolina Low Country, 1670-1920. New York: Oxford University Press, 1989.

Cole, Arthur H. "Agricultural Crazes: A Neglected Chapter in American Economic History." American Economic Review 16, no. 4 (1926): 622-39.

Cook, Lisa D. "Inventing Social Capital: Evidence from African American Inventors, 1843-1930." Explorations in Economic History 48, no. 4 (2011): 507-18.

CropLife International. "The Cost and Time Involved in the Discovery, Development and Authorization of a New Plant Biotechnology Derived Trait," 2013. Available at www.croplife.org/PhillipsMcDougallStudy (examined 28 September 2013).

DeBow's Review. Various issues.

Duggar, J. F. "Descriptions and Classifications of Varieties of American Upland Cotton." Alabama Experiment Station Bulletin, no. 149 (1907).

Dupree, A. Hunter. Science in the Federal Government: A History of Policies and Activities to 1940. Cambridge, MA: Harvard University Press, 1957.

Edgefield [SC] Advertiser. Various issues.

Farmer's Register. Various issues.

Farmers' Cabinet. Various issues. 
Farrar, John. "Letter on Agricultural Humbugs." Southern Cultivator 11, no. 4 (1853): 108.

Fullilove, Courtney. The Profit of the Earth: The Global Seeds of American Agriculture. Chicago: University of Chicago Press, 2017.

Gans, Joshua, David Hsu, and Scott Stern. "The Impact of Uncertain Intellectual Property Rights on the Market for Ideas: Evidence for Patent Grant Delays." Management Science 54, no. 5 (2008): 982-97.

Garber, Peter M. Famous First Bubbles: The Fundamentals of Early Manias. Cambridge, MA: MIT Press, 2000.

Gray, Lewis C. History of Agriculture in the Southern United States to 1860, Vol. 2. Washington, DC: Carnegie Institute, 1933.

Hite, J. E. Community Production and Distribution of Cotton Planting Seed in a One-Variety Cotton Community, USDA Circ. No. 286. Washington, DC: U.S. Department of Agriculture, 1933.

Johnson, Walter. River of Dark Dreams: Slavery and Empire in the Cotton Kingdom. Cambridge, MA: Harvard University Press, 2013.

Jones, George Noble. Florida Plantation Records from the Papers of George Noble Jones, edited by Ulrich Bonnell Phillips and James David Glunt. St. Louis, MO: Missouri Historical Society, 1927.

Jones, Jethro V. "Letter." Transactions of the Southern Central Agricultural Society, from Its Organization in 1846 to 1851, 406-8. Macon, GA: Southern Central Agricultural Association of Georgia, 1852.

Jordan, Weymouth T. Hugh Davis and His Alabama Plantation. Montgomery, AL: University of Alabama Press, 1948.

Kalaitzandonakes, Nicholas, Julian M. Alston, and Kent J. Bradford. "Compliance Costs for Regulatory Approval of New Biotech Crops.” Nature Biotechnology 25 (2007): 509-11.

Khan, B. Zorina. The Democratization of Invention: Patents and Copyrights in American Economic Development, 1790-1920. New York: Cambridge University Press, 2005.

Khan, B. Zorina, and Kenneth L. Sokoloff. "'Schemes of Practical Utility': Entrepreneurship and Innovation among 'Great Inventors' in the United States, 1790-1865.” Journal of Economic History 53, no. 2 (1993): 289-307.

Klein, Benjamin, and Keith B. Leffler. "The Role of Market Forces in Assuring Contractual Performance." Journal of Political Economy 89, no. 4 (1981): 61541.

Kloppenberg, Jack Ralph, Jr. First the Seed: The Political Economy of Plant Biotechnology, $2^{\text {nd }}$ ed. Madison: University of Wisconsin Press, 2004.

Liptak, Adam. "Supreme Court Supports Monsanto in Seed-Replication Case." New York Times, 13 May 2013. Available at https://www.nytimes.com/2013/05/14/ business/monsanto-victorious-in-genetic-seed-case.html.

Lyman, Joseph B. Cotton Culture. New York: Orange-Judd, 1868.

Meyer, David R. Networked Machinists: High Technology Industries in Antebellum America. Baltimore, MD: Johns Hopkins University Press, 2006.

Mississippi Free Trader. Various issues.

Mitchell, G. D. "Pomegranate Prolific." Southern Cultivator 8, no. 1 (1850): 8.

Moore, John Hebron. "Cotton Breeding in the Old South.” Agricultural History 30, no. 3 (1956): 95-104. 


\section{Cottonseed Markets in the Antebellum American South 235}

- The Emergence of the Cotton Kingdom in the Old Southwest, Mississippi, 1770-1860. Baton Rouge: Louisiana State University Press, 1988.

New Orleans Commercial Bulletin. Various issues

New York Times. Various issues.

Niles' National Register. Various issues.

No author. U.S. Supreme Court, Bowman v. Monsanto Co. (13 May) 657 F.3d 1341. Washington, DC: GPO, 2013.

Nutt, Haller. "Egyptian Cotton Cultivated in Mississippi." Farmer's Register 9, no. 5 (1841): 312-14.

Olmstead, Alan L., and Paul W. Rhode. Creating Abundance: Biological Innovation and American Agricultural Development. New York: Cambridge University Press, 2008a.

- "Biological Innovation and Productivity Growth in the Antebellum Cotton Economy." Journal of Economic History 68, no. 4 (2008b): 1123-71.

Philips, Martin W. “Cotton Seed.” Southern Cultivator 6, no. 7 (1848a): 101.

—. "Sugar-Loaf Cotton." Southern Cultivator 6, no. 9 (1848b): 131.

"Improved Cotton Seed." Southern Cultivator 7, no. 1 (1849): 11.

. "Gen. Mitchell's Prolific Pomegranate Explanation." Southern Cultivator 8, no. 11 (1850a): 65.

. "Mastodon Cotton." Southern Cultivator 8, no. 1 (1850b): 5.

—. "Pomegranate Cotton Seed." Southern Cultivator 8, no. 6 (1850c): 92.

_. "More about that Pomegranate." Southern Cultivator 9, no. 7 (1851a): 108.

- "Testing Land Chemically--Pomegranate Cotton." Southern Cultivator 9, no.

6 (1851b): 90 .

—_. "The Jethro Cotton: Testimony." Southern Cultivator 9, no. 2 (1851c): 21.

_. "A New Variety of Cotton Seed." American Cotton Planter 3, no. 5 (1855a): 150.

—. "The Different Varieties of Cotton Seed." DeBow's Review (1855b): 224-25.

Phillips, Ulrich B. American Negro Slavery: A Survey of the Supply, Employment, and Control of Negro Labor, as Determined by the Plantation Regime. New York: D. Appleton, 1918.

Porcher, Richard D., and Sarah Fick. The Story of Sea Island Cotton. Charleston, SC: Charleston Museum, 2005.

Raymond [MS] Gazette. Various issues.

Riley, Franklin L., ed. "Diary of a Mississippi Planter, January 1, 1840 to April, 1863." Publications of the Mississippi Historical Society 10 (1909): 305-483.

Rhode, Paul W. "Replication: Biological Innovation without Intellectual Property Rights: Cottonseed Markets in the Antebellum American South.” Ann Arbor, MI: Inter-university Consortium for Political and Social Research [distributor], 202011-19. https://doi.org/10.3886/E127061V1.

Smith, C. Wayne, and J. Tom Cothren, eds. Cotton: Origin, History, Technology, and Production. New York: John Wiley, 1999.

Smith, J. Dickson, ed. A Practical Treatise on Agriculture to which is Added the Author's Published Letter by David Dickson, Sparta Georgia. Macon, GA: J. W. Burke, 1870.

Sokoloff, Kenneth L., and B. Zorina Khan. "The Democratization of Invention during Early Industrialization: Evidences from the United States, 1790-1846." Journal of Economic History 50, no. 2 (1990): 363-78. 
Southern Agriculturist. Various issues.

Southern Banner. Various issues.

Southern Cultivator. Various issues.

Thomson, Ross. Structures of Change in the Mechanical Age: Technological Innovation in the United States, 1790-1865. Baltimore, MD: Johns Hopkins University Press, 2009.

Thorpe, T. B. “Cotton and Its Cultivation.” Harper's Magazine (1854): 447-63.

True, Alfred C. A History of Agricultural Experimentation and Research in the United States, 1607-1925, USDA Misc. Publication no. 251. Washington, DC: GPO, 1937.

Turner, Joseph A. The Cotton Planter's Manual, Being a Compilation of Facts from the Best Authorities on the Culture of Cotton; Its Natural History, Chemical Analysis, Trade, and Consumption; and Embracing a History of Cotton and the Cotton Gin. New York: C. M. Saxton, 1857.

Tyler, F. J. "Varieties of American Upland Cotton." U.S. Bureau of Plant Industry Bulletin, no. 163. Washington, DC: GPO, 1910.

U.S. Census Office. Seventh Census, 1850, Statistical View of the United States, Embracing its Territory, Population-White, Free Colored, and Slave-Moral and Social Condition, Industry, Property, and Revenue. Washington, DC: GPO, 1854.

U.S. Patent Office. Annual Report of the Commissioner of Patents, 1848, Pt. II: Agriculture. Washington, DC: GPO, 1849.

- Annual Report of the Commissioner of Patents, 1849, Pt. II: Agriculture. Washington, DC: GPO, 1850.

- Annual Report of the Commissioner of Patents, 1850, Part II: Agriculture. Washington, DC: GPO, 1851.

- Annual Report of the Commissioner of Patents, 1854, Part III: Agriculture. Washington, DC: GPO, 1855.

U.S. Treasury. A Statement of the Receipts and Expenditures of the Government. Washington, DC: GPO, various years, 1854-1862.

Vick, H. W. "Col. Vick on the Improvement of Cotton." Southern Cultivator 9, no. 9 (1851): 129.

Vicksburg Sentinel. Various issues.

Ware, Jacob Osborn. "Origin, Rise, and Development of American Upland Cotton Varieties and Their Status at Present." Mimeo. Fayetteville, AR: University of Arkansas College of Agriculture, Agricultural Experiment Station, 1950.

Yazoo City Whig. Various issues.

Yazoo Democrat. Various issues.

\section{Plantation Records Consulted}

Allen, James. Plantation Book. Z/0014.000, reel 35978. Mississippi Department of Archives and History (Jackson, MS).

Julien Sidney Devereux Family Papers, 1766-1908, 1931, 1941. Series G, Part 1, Reel 36-41. Stampp, Kenneth M., ed. Records of Ante-bellum Southern Plantations from the Revolution through the Civil War [Microfilm]. Frederick, MD: University Publications of America, 1985-2000. Series. G. Selections from the University of Texas.

English, John. Mississippi Cotton Plantation Diary and Journal. Gilder Lehrman Institute of American History. 


\section{Cottonseed Markets in the Antebellum American South}

McDonald Furman Papers. Duke University. David M. Rubenstein Rare Book, Manuscript, and Special Collections Library (Durham, NC).

Papers of James Henry Hammond, 1795-1865. RASP, Ser. A, pt. 1, reels 1-15. Stampp, Kenneth M., ed. Records of Ante-bellum Southern Plantations from the Revolution through the Civil War [Microfilm]. Frederick, MD: University Publications of America, 1985-2000. Series A. Selections from the South Caroliniana Library, University of South Carolina.

Jenkins, Robert Charmichael, Papers. Historic Natchez Foundation.

Law, William. Papers, 1761-1890. Duke University. David M. Rubenstein Rare Book, Manuscript, and Special Collections Library (Durham, NC).

Francis Terry Leak Papers, 1839-1865. Ser. J, pt. 6, reels 24-27. Stampp, Kenneth M., ed. Records of Ante-bellum Southern Plantations from the Revolution through the Civil War [Microfilm]. Frederick, MD: University Publications of America, 19852000. Series J. Selections from the Southern Historical Collection, Manuscripts Department, Library of the University of North Carolina at Chapel Hill.

Duncan and Dugal McCall Plantation Journals, 1832-1854. Ser. F, pt. 1, reels 4-5. Stampp, Kenneth M., ed. Records of Ante-bellum Southern Plantations from the Revolution through the Civil War [Microfilm]. Frederick, MD: University Publications of America, 1985-2000. Series F. Selections from the Manuscript Department, Duke University Library.

Massenburg, Nicholas Bryor. Papers, 1834-1851. 908. University of North Carolina. Wilson Library, Southern Historical Collection, Manuscripts Department (Chapel Hill, NC).

Reynolds, William Sims. Plantation Journal, 1836-44. University of South Carolina. South Caroliniana Library (Columbia, SC).

Lewis Stirling and Family Papers, 1784-1865. Ser. I, pt. 2, reels 21-25. Stampp, Kenneth M., ed. Records of Ante-bellum Southern Plantations from the Revolution through the Civil War [Microfilm]. Frederick, MD: University Publications of America, 1985-2000. Series I. Selections from Louisiana State University.

\section{Newspaper Sources Consulted}

Readex Early American Newspapers, Newsbank's GenealogyBank, the Library of Congress Chronicling America; Gale's 19th Century Newspapers, Ancestry's Newspapers.com, Proquest American Periodicals, Proquest Historical Newspapers, Google Historical Newspapers, Access Newspaper Archive, Florida Digital Newspaper Library, Digital Library of Georgia: Historical Newspapers; Louisiana Digital Library, North Carolina Newspaper: DigitalNC; Historical Newspapers of South Carolina; and The Portal to Texas History: Texas Digital Newspaper Program, as well as selected microfilmed newspapers from Harvard University Library, Yale University Library, the Library of Congress, and the Mississippi Department of Archives and History.

Price Quotations Are from the Following Publications

Abbeville [SC] Banner; Affleck's Rural Almanac; Alabama Beacon (Greensboro); Alabama Journal (Montgomery); Albany [GA] Patriot; American Banner (Yazoo City, MS); American Farmer; Arkansas Banner (Little Rock); Arkansas Gazette (Little Rock); Augusta Chronicle; Augusta Chronicle and Sentinel; Augusta Constitutionalist; Augusta Dispatch; Autauga [AL] Citizen; Baton Rouge Gazette; Cahaba [AL] 
Gazette; Camden [SC] Journal; Central Georgian (Sandersville); Charleston Courier; Charleston Mercury; Charlotte [NC] Democrat; Charlotte [NC] Journal; Cheraw [SC] Gazette; Clarksville [TX] Northern Standard; Columbia [SC] Enquirer; Columbia [SC] Times; Columbus [GA] Enquirer; Columbus [MS] Democrat; Concordia Intelligencer (Vidalia, LA); Daily Confederation (Montgomery, AL); Daily South Carolinian (Columbia); De Bow's Review; Edgefield [SC] Advertiser; Eufaula [AL] Spirit of the South; Farmer's Register; Farmers' Gazette and Cheraw [SC] Advertiser; Fayetteville [NC] Observer; Federal Union (Milledgeville, GA); Feliciana [LA] Democrat; Flag of the Union (Jackson, MS); Floridian and Advocate (Tallahassee); Floridian and Journal (Tallahassee);Galveston [TX] Commercial and Weekly Price Current; Georgetown [SC] American; Georgia Constitutionalist (Augusta); Georgia Constitutionalist and Republic (Augusta); Georgia Jeffersonian (Griffin); Georgia Journal and Messenger (Macon); Georgia Messenger (Ft. Hawkins); Georgia Telegraph (Macon); Grove Hill [AL] Clark County Democrat; Hayneville [AL] Chronicle; Holly Springs [MS] Gazette; Huntsville [AL] Democrat; Independent Press (Abbeville, SC); Jackson [MS] Mississippian; Jackson [MS] Southron; Jeffersonian Republican (New Orleans); Keowee Courier (Pickens, SC); Liberty [MS] Advocate; Livingston [AL] Voice of Sumter; Macon [GA] Telegraph; Memphis Bulletin; Memphis Daily Eagle and Enquirer; Mississippi Democrat (Carrollton); Mississippi Free Trader (Natchez); Mississippi Free Trader and Natchez Gazette; Mississippi Palladium (Holly Springs); Mississippi True Democrat (Pauling); Mississippian (Jackson); Mississippian and State Gazette (Jackson); Mobile Advertiser; Mobile Register; Monroe Democrat (Aberdeen, MS); Nacogdoches [TX] Chronicle; Natchez Courier; New Bern [NC] Spectator; New Orleans Commercial Bulletin; New Orleans Crescent; New Orleans Daily Delta; New Orleans Times-Picayune; North Carolina Standard (Raleigh); Northern Alabamian (Tuscumbia); Penfield [GA] Temperance Banner; Pensacola [FL] Gazette; Port Gibson [MS] Correspondent; Port Gibson [MS] Herald; Port Gibson [MS] Herald, and Correspondent; Raleigh [NC] Register; Raymond [MS] Gazette; Red-Lander (San Augustine, TX); Republican Banner (Nashville, TN); Savannah Daily Republican; Savannah Georgian; Scientific American; Selma [AL] Reporter; Southern Agriculturist; Southern Argus (Columbus, MS); Southern Banner (Holly Springs, MS); Southern Cabinet; Southern Cultivator; Southern Patriot (Charleston, SC); Southern Recorder (Milledgeville, GA); Southern Reformer (Jackson, MS); Southern Sentinel (Columbus, GA); Southern Statesman (Prattville, AL); South-Western (Shreveport, LA); Star State Patriot (Marshall, TX); State Gazette (Austin, TX); Sumner [SC] Banner; Tarrboro [NC] Press; Texas Ranger (Washington); Vicksburg [MS] Sentinel; Vicksburg [MS] Whig; Washington [AR] Telegraph; Weekly Conservative (Aberdeen, MS); Weekly Panola [TX] Star; Western Carolinian (Salisbury, NC); Wetumpka [AL] Spectator; Yazoo [MS] Democrat; Yazoo City [MS] Whig; Yorkville [SC] Enquirer. 